\title{
Niche differentiation of Dinophysis acuta and D. acuminata in a stratified fjord
}

\author{
Baldrich Ángela M. 1, 10, * , Pérez-Santos Iván 2, 3, Álvarez Gonzalo 4, 5, Reguera Beatriz ${ }^{6}$, \\ Fernández-Pena Concepción ${ }^{7}$, Rodríguez-Villegas Camilo ${ }^{1,10}$, Araya Michael ${ }^{5}$, Álvarez Francisco ${ }^{5}$, \\ Barrera Facundo ${ }^{8}$, Karasiewicz Stephane ${ }^{9}$, Díaz Patricio A. ${ }^{2,} 10$
}

${ }^{1}$ Programa de Doctorado en Ciencias, mención Conservación y Manejo de Recursos Naturales, Universidad de Los Lagos, Camino Chinquihue km 6, Puerto Montt, Chile

${ }^{2}$ Centro i mar, Universidad de Los Lagos, Casilla 557, Puerto Montt, Chile

${ }^{3}$ Centro de Investigación Oceanográfica COPAS Sur-Austral, Universidad de Concepción, Chile

4 Departamento de Acuicultura, Universidad Católica del Norte, Coquimbo, Chile

${ }^{5}$ Centro de Investigación y Desarrollo Tecnológico en Algas (CIDTA), Universidad Católica del Norte, Coquimbo, Chile

${ }^{6}$ Centro Oceanográfico de Vigo, Instituto Español de Oceanografía (IEO), Vigo, Spain

${ }^{7}$ Centro Oceanográfico de A Coruña, Instituto Español de Oceanografía (IEO), A Coruña, Spain

${ }^{8}$ Center for Climate and Resilience Research (CR2), Facultad de Ciencias Naturales y Oceanográficas Universidad de Concepción \& Departamento de Química Ambiental Universidad Católica de la Santísima Concepción, Concepción, Chile

${ }^{9}$ Laboratory of Environment Resources, Boulogne- sur- Mer, French Research Institute for the

Exploitation of the Sea (IFREMER), Issy-les-Moulineaux, France

${ }^{10} \mathrm{CeBiB}$, Universidad de Los Lagos, Casilla 557, Puerto Montt, Chile

* Corresponding author : Angela M. Baldrich, email address : ambaldrich@gmail.com

\begin{abstract}
:
Dinophysis acuta and D. acuminata are associated with lipophilic toxins in Southern Chile. Blooms of the two species coincided during summer 2019 in a highly stratified fjord system (Puyuhuapi, Chilean Patagonia). High vertical resolution measurements of physical parameters were carried out during $48 \mathrm{~h}$ sampling to i) explore physiological status (e.g., division rates, toxin content) and ii) illustrate the fine scale distribution of D. acuta and D. acuminata populations with a focus on water column structure and cooccurring plastid-bearing ciliates. The species-specific resources and regulators defining the realized niches (sensu Hutchinson) of the two species were identified. Differences in vertical distribution, daily vertical migration and in situ division rates (with record values, $0.76 \mathrm{~d}-1$, in $D$. acuta), in response to the environmental conditions and potential prey availability, revealed their niche differences. The Outlying Mean Index (OMI) analysis showed that the realized niche of D. acuta (cell maximum $7 \times 103$ cells $L-1$ within the pycnocline) was characterized by sub-surface estuarine waters (salinity $23-25$ ), lower values of turbulence and PAR, and a narrow niche breath. In contrast, the realized niche of D. acuminata (cell maximum $6.8 \times 103$ cells $L-1$ just above the pycnocline) was characterized by fresher (salinity $17-20$ ) outflowing surface waters, with higher turbulence and light intensity and a wider niche breadth. Results from OMI and PERMANOVA analyses of co-occurring microplanktonic ciliates were compatible with the hypothesis of species such as those from genera Pseudotontonia and Strombidium constituting an alternative ciliate prey to Mesodinium. The D. acuta cell maximum was associated with DSP (OA and
\end{abstract}


DTX-1) toxins and pectenotoxins; that of D. acuminata only with pectenotoxins. Results presented here contribute to a better understanding of the environmental drivers of species-specific blooms of Dinophysis and management of their distinct effects in Southern Chile. Previous article

\section{Highlights}

$48 \mathrm{~h}$ of high frequency physical data for co-occurring blooms of 2 Dinophysis species. $D$. acuta (exceptional $\mu$ ) thin layer briefly disrupted by an increase in turbulence. Co-occurring $D$. acuminata and $D$. acuta blooms showed a clear niche differentiation. Niche analysis results compatible with putative ciliate prey other than Mesodinium. D . acuta maximum associated with DSP toxins (OA, DTX1), D. acuminata with PTX2 only.

Keywords: Dinophysis acuminata, Dinophysis acuta, Realized niche, in situ division rates, Microplanktonic ciliate prey, DSP toxins, Pectenotoxins, Chilean fjords 


\section{Introduction}

57 Species of Dinophysis have drawn attention worldwide due to their capacity to produce two groups of lipophilic toxins. The first group, okadaic acid (OA) and its derivatives, the dinophysistoxins (DTX), cause diarrhetic shellfish poisoning (DSP) (Gestal-Otero, 2014; Reguera et al., 2014; Yasumoto et al., 1980); the second group, the pectenotoxins (PTX),

61 are hepatotoxic in cellular assays (Munday, 2014), and cause negative effects on early life stages of fish (Rountos et al., 2019) and shellfish (Gaillard et al., 2020). The production of one or both groups of toxins is very variable, even between strains of the same species from

64 different regions (Reguera et al., 2014).

65 Accumulation of Dinophysis toxins, even at low cell densities $\left(10^{2}-10^{3}\right.$ cells $\left.\mathrm{L}^{-1}\right)$, by filter-

66 feeding bivalves may exceed seafood safety regulatory thresholds (160 $\mu \mathrm{g}$ OA equiv. $\mathrm{kg}^{-1}$ meat) (European Commission, 2019) and cause lengthy harvesting quarantines. The impact of Dinophysis blooms is affected by the toxic potential of the local strains of Dinophysis,

69 i.e., toxin profile and content, and by the specific transformation of the toxins by each shellfish species (Blanco et al., 2018). The main species which cause shellfish toxicity in

71 western Europe are Dinophysis acuminata and to a lesser extent D. acuta (Fernández et al., 72 2019; Reguera et al., 2014; Swan et al., 2018).

73 Earlier studies in Chilean fjords focused on general aspects of the phytoplankton communities, including Dinophysis species (Avaria, 2008; Cassis et al., 2002; Pizarro et al.,

75 2018; Seguel et al., 2005); the relationship of Dinophysis populations with environmental 76 conditions (Alves-de-Souza et al., 2019; Alves-de-Souza et al., 2014; Díaz et al., 2011;

77 Muñoz, 1992); and the detection and quantification of Dinophysis toxins in the framework 78 of monitoring programmes (Fux et al., 2011; García et al., 2004; Pizarro et al., 2011; Uribe 79 et al., 2001). These studies showed that Dinophysis acuta and D. acuminata are frequently 
recorded in the southernmost regions in recent decades, and that their blooms pose a threat to public health, artisanal fisheries and the mussel industry. However, little is known about their species and site-specific requirements and the contribution of each species to toxic outbreaks (Díaz et al., 2019a).

Dinophysis species are obligate kleptoplastidic mixotrophs. They require ciliate prey (e.g., Mesodinium), light and nutrients for sustained growth (Kim et al., 2012; Kim et al., 2008; Park et al., 2006). Other plastid-bearing ciliate genera, such as Cyrotostrombidium, Laboea and Strombidium have been suggested as potential alternative prey (Kim et al., 2012; Stoecker et al., 2009). Field studies have shown that each Dinophysis species or even strain has different environmental windows for growth (Escalera et al., 2006; Maestrini, 1998). Thus, D. acuminata is considered a cosmopolitan species distributed over a wide range of salinity and temperature, while D. acuta is a temperate water species usually found in narrow ranges for these two environmental variables (Moita et al., 2006; Reguera et al., 2012). Results from Galician-Portuguese coastal waters reveal that when D. acuminata and D. acuta co-occur, they are vertically segregated with their cell maxima in different water masses (Díaz et al., 2019b; Escalera et al., 2006). These observation suggested that the two species have different physiological and behavioural adaptations. Laboratory culture studies confirmed the different responses of the two species to light intensity and quality (García-Portela et al., 2018; Kim et al., 2008), turbulence (García-Portela et al., 2019) and nitrogen sources (García-Portela et al., 2020; Hattenrath-Lehmann and Gobler, 2015).

A detailed understanding of the site and strain specific factors that trigger $\mathrm{HAB}$ development is needed to model their population dynamics and prevent or minimize their negative consequences (GEOHAB, 2011). Dinoflagellate blooms, in particular those of 103 Dinophysis species, are often associated with stratified conditions (GEOHAB, 2008). 
Fjords are highly stratified systems, and the persistence and strength of stratification

105 appears to be one of the most important conditions for Dinophysis bloom development

106 (Raine et al., 2018; Roy et al., 2018). A key question is to identify the microstructure

107 characteristics of a given stratified system, i.e., temperature and salinity gradients, and

108 pycnocline depths, that select a determined species' strain. High resolution measurements

109 of the vertical distribution of physical and chemical properties of the water column are

110 needed, as well as an evaluation of the physiological status of the cells (in situ division rate)

111 and prey availability. These measurements allow distinction between actively dividing or

112 recently advected senescent cells of the target species and descriptions of their behaviour.

113 The Hutchinson concept of ecological niche (Hutchinson, 1957) is a useful approach to

114 understand the relationship between a species distribution and its environment (Colwell and

115 Rangel, 2009; Holt, 2009; Pagel and Schurr, 2012). Hutchinson postulates two components

116 for the ecological niche of a given species. First, the fundamental niche: the $n$-dimensional

117 hypervolume within which the population of a species can persist, survive, and reproduce

118 indefinitely. The fundamental niche is not constrained by any biological interactions.

119 Second, the realized niche, i.e., the proportion of the fundamental niche within which the

120 species actually persists. The realized niche takes into account the effect of abiotic variables

121 and biological interactions (Hutchinson, 1957). This niche perspective has been applied to

122 the study of different groups of phytoplankton both in laboratory (fundamental niche) and

123 field (realized niche) conditions (Brun et al., 2015; Irwin et al., 2012; Litchman et al.,

124 2012). The Outlying Mean Index (OMI) analysis proposed by Dolédec et al. (2000) is a

125 useful ordination method for describing phytoplankton species niches (Grüner et al., 2011;

126 Hernández-Fariñas et al., 2015; Sutani et al., 2014), including those responsible for HAB

127 events (Alves-de-Souza et al., 2019; Karasiewicz et al., 2018; Karasiewicz et al., 2020). 
128 During late summer (February) 2019, high density blooms of D. acuminata and D. acuta 129 co-occurred in Southern Chile, offering an opportunity to undertake a detailed niche 130 partitioning study. In the present study, results were analysed from the niche perspective, 131 using the Outlying Mean Index (Dolédec et al., 2000). In situ measurements were made of 132 division rates and toxin content of both Dinophysis species during two daily cycles, and of 133 daily vertical migration and distribution in relation to potential ciliate prey. The hypothesis 134 was that different physiological and behavioural traits determine bloom development 135 success of $D$. acuminata and D. acuta under a distinct set of conditions (realized niche) 136 when they co-occur in stratified fjords. The main objective was to identify the 137 environmental variables, during $48 \mathrm{~h}$ intensive sampling, which define the realized niche of 138 D. acuta and D. acuminata and explain their microscale distribution in Puyuhuapi Fjord.

\section{Materials and Methods}

141 2.1. Study area

142 Puyuhuapi Fjord (PF), Aysén Region, northern Patagonia ( 4450`S; Fig. 1) is $100 \mathrm{~km}$

143 long with a N-NE orientation. The fjord is connected to Moraleda Channel at the mouth and 144 with Jacaf Channel close to the head in a region with extremely high $\left(\sim 3,500-4000{\mathrm{~mm} \mathrm{yr}^{-}}^{-}\right.$ $145^{1}$ ) precipitation (Sauter, 2020). The main freshwater input is the Cisnes River (average 146 streamflow $218 \mathrm{~m}^{3} \mathrm{~s}^{-1}$ ), which flows into the middle part of the fjord (Schneider et al., 147 2014). Smaller rivers Ventisquero (average streamflow $40 \mathrm{~m}^{3} \mathrm{~s}^{-1}$ ), Marta and Uspallante (no 148 data available) also discharge freshwater into this fjord (Calvete and Sobarzo, 2011).

149 Waters from the northern area of PF are more brackish than those from the southern area 150 except in winter, when this pattern may be reversed due to the intrusion of oceanic water 151 through Jacaf Channel, and vertical stratification is very variable (Schneider et al., 2014). 
152 The circulation is of two-layered estuarine-type, with a variable $(5-10 \mathrm{~m})$ estuarine surface 153 layer (EW) and a more uniform saltier lower layer, the Subantarctic Water (SAAW, 154 salinities > 33 ) reaching $150 \mathrm{~m}$ depth (Silva and Calvete, 2002). Mixing at the interface of 155 the two layers yields Modified Subantarctic Water (MSAAW, salinities 31 to 33) 156 (Schneider et al., 2014). Depending on the freshwater contribution, different water masses 157 in the PF (as well as other fjords and channels in Patagonia) can be identified in the top 158 layer: the Estuarine Fresh Water (EFW, with salinities 11 to 21) and the Estuarine Saline 159 Water (ESW, with salinities 21 to 31 ). When salinity is less than 11, the water is classified 160 as Fresh Water (FW) (Pérez-Santos et al., 2014).

\subsection{Field sampling}

163 High vertical resolution measurements of physical parameters were carried out during a 48

164 h cell cycle study of Dinophysis species and distribution of co-occurring plastid-bearing 165 micro-ciliates. A fixed station was sampled from 26 to 28 February 2019 in PF. This fjord,

166 the only one in the region with two connections with the open sea, has the highest water 167 residence time (Díaz et al., 2021). It was selected as a hot spot of Dinophysis blooms and 168 DSP outbreaks in Southern Chile according to the official monitoring data (IFOP) over the 169 last ten years (data not shown). Vertical profiles of temperature, salinity, and in vivo chl $a$ 170 fluorescence were obtained with an AML Oceanographic CTD profiler 171 (http://www.amloceanographic.com) model Metrec-XL equipped with a Turner Designs 172 CYCLOPS-7 fluorometer (excitation $460 \mathrm{~nm}$, emission 620-715 nm). This fluorescence 173 sensor outputs an analog voltage proportional to the chl $a$ concentration. CTD fluorescence 174 data from a northern Patagonian fjord $\left(41.6^{\circ} \mathrm{S} / 72.85^{\circ} \mathrm{W}\right)$ and chl $a$ in bottle samples 175 collected at standard depths $(0,5,10,15,25,50,75,100,150$, and $200 \mathrm{~m})$ were highly 
176 correlated $\left(\mathrm{R}^{2}=0.987\right)$ and used to convert the CYCLOPS-7 output voltage into chl $a$ 177 concentration. The (CTD) probe was cast every $2 \mathrm{~h}$ from the surface to $50 \mathrm{~m}$ depth. Vertical 178 distributions of turbulence microstructure were measured with a Self-Contained 179 Autonomous Micro Profiler (SCAMP) $(100 \mathrm{~Hz})$. Processing of the CTD and SCAMP data 180 was carried out with the software provided by the manufacturer and depicted using the 181 Ocean Data View software version 5.1 (Schlitzer, 2019). A Photosynthetically Active 182 Radiation (PAR) sensor was used to obtain radiation data at the same sampling rate as the 183 temperature and conductivity sensors. The turbulent kinetic energy dissipation rate $\left(\varepsilon, \mathrm{m}^{2}\right.$ $184 \mathrm{~s}^{-3}$ ) was estimated by applying the Batchelor spectrum to the vertical gradients of 185 temperature (Luketina and Imberger, 2001).

186 Plankton nets $(20 \mu \mathrm{m}$ mesh) were towed vertically from $20 \mathrm{~m}$ to the surface every hour and 187 aliquots of $100 \mathrm{~mL}$ fixed with neutral Lugol's iodine solution (Lovegrove, 1960) to 188 estimate in situ daily average division rates $(\mu)$ of the two species, as in Velo-Suárez et al. 189 (2009). For quantitative analysis of Dinophysis species and their potential microciliate prey, 190 water samples of $100 \mathrm{~mL}$, were collected every $2 \mathrm{~h}$ at $2 \mathrm{~m}$ intervals, from 0 to $20 \mathrm{~m}$, and at $19125 \mathrm{~m}$ and $30 \mathrm{~m}$ with $5 \mathrm{~L}$ Niskin bottle, and fixed with neutral Lugol's iodine solution 192 (Lovegrove, 1960). In addition, 2 L samples were collected at each depth on 27 and 28 193 February 2019 to estimate division rates at specific depths $\left(\mu_{m i n}\right)_{z}$ and the depths where the 194 maximal values of $\left(\mu_{\min }\right)_{z}$ were estimated. These samples were collected at 10:00 h LT, the 195 time of day when maximal cell division of $D$. acuta was expected, filtered through $20 \mu \mathrm{m}$ 196 nytex filter and re-suspended in $50 \mathrm{~mL}$ of seawater with Lugol's iodine solution, a protocol 197 used to increase counting resolution of D. acuta and D. acuminata as in Velo-Suárez et al. 198 (2009). 
199 For toxin analyses, bottle samples were collected every $2 \mathrm{~h}$ at $4 \mathrm{~m}$ intervals from surface to $20020 \mathrm{~m}$ (6 fixed depths), and $1 \mathrm{~L}$ aliquots filtered through Whatman GF/F fiberglass filters 201 (25 $\mathrm{mm} \varnothing, 0.7 \mu \mathrm{m}$ pore size) (Whatman, Maidstone, England). The filters and filtered 202 material were placed in a cryotube, mixed with $1 \mathrm{~mL}$ analysis grade methanol and stored in 203 the laboratory at $-20^{\circ} \mathrm{C}$ until analysis. The field sampling is summarized in Fig. S1.

204

\subsection{Nutrient analyses}

206 Water samples for inorganic nutrient $\left(\mathrm{NO}_{3}{ }^{-}, \mathrm{NO}_{2}^{-}, \mathrm{PO}_{4}{ }^{3-}\right.$, and $\left.\mathrm{Si}(\mathrm{OH})_{4}\right)$ analyses were 207 taken three times throughout the $48 \mathrm{~h}$ sampling, using $50 \mathrm{~mL}$ syringes directly connected to 208 the spigot of the Niskin bottle at each sample depth (i.e., 2, 5, 10, 15, 20 and $50 \mathrm{~m}$ ). 209 Dissolved inorganic nutrients were analysed with a Seal AA3 AutoAnalyzer, as in 210 Grasshoff et al. (1983) and according to standard methods for seawater analysis (Kattner 211 and Becker, 1991). Ammonia analyses were omitted for logistic reasons, i.e., the 212 impossibility to ensure analyses of this labile molecule very soon after collection in remote 213 areas in southern Chile.

\section{2.4. Phytoplankton analyses}

216 Sedimentation chambers of $10 \mathrm{~mL}$ were used to sediment aliquots of each Lugol-fixed

217 bottle sample. Samples were left to sediment for $24 \mathrm{~h}$ for quantitative analyses of 218 Dinophysis species and ciliates with inverted microscopes Olympus CX40 (Olympus, 219 Japan) and Nikon Eclipse TE300 (Nikon, Japan) respectively, according to Utermöhl 220 (Utermöhl, 1958). To count Dinophysis species and ciliates, the whole surface of the 221 chamber was scanned at a magnification of $\mathrm{x} 100$, so that the detection limit was 100 cells $222 \mathrm{~L}^{-1}$. Ciliates were identified to genus, or to species level when possible using 
223 magnifications of $\mathrm{x} 200$ and $\mathrm{x} 400$. Taxonomic nomenclature complied with the World

224 Register of Marine Species (WORMS, http://www.marinespecies.org/, last access June $\left.22510^{\text {th }}, 2020\right)$.

\section{2.5. Division rates}

228 Aliquots $(1 \mathrm{~mL})$ of each Lugol-fixed net haul and concentrated $2 \mathrm{~L}$ bottle samples were 229 analysed using Sedgewick-Rafter counting slides with an inverted microscope (Olympus 230 CX40). Net haul samples were used to get the daily average specific division rate ( $\mu$ ) of $D$. 231 acuta and D. acuminata in the water-column $(0-20 \mathrm{~m})$. Two cell cycle stages of each 232 species were counted-dividing (paired cells) and recently divided cells (incomplete 233 development of the left sulcal list). These stages were considered as terminal events to 234 estimate in situ division rates with a post-mitotic index (Reguera et al., 2003) adapted from 235 the mitotic index model of Carpenter and Chang (1988). Vegetative or asexual division in 236 Dinophysis occurs by desmoschisis. In the division process, the two daughter cells remain 237 attached by their dorsal margins in an intercalary growth zone, the dorsal megacytic bridge, 238 forming cell pairs $(p)$ that remain together for a period of time that varies among 239 Dinophysis species and according to dominant environmental conditions. The sulcal lists of 240 the mother cells are not evenly distributed. This is an easily distinguished morphological

241 character to recognize the recently divided daughter cells $\left(I_{r}\right)$. A minimum of 300 cells of 242 each species (depending on their abundance in the field) was examined for each data point 243 of the frequency graph. Frequencies $(f)$ of cells undergoing mitosis $\left(f_{p}\right)$ and of recently 244 divided cells $\left(f_{r}\right)$ at each sampling time were estimated according to: 


$$
f_{p}+f_{r}=\frac{p+\frac{I_{r}}{2}}{I_{c}+p+\frac{I_{r}}{2}}
$$

246 where $f_{p}=$ frequency of cell pairs; $f_{r}=$ frequency of recently divided cells; $I_{c}=$ fully

247 developed (complete) cells. In all cases, examination was continued on samples collected 248 during the hours of reproduction until at least 30 events (dividing cells) had been observed.

249 The daily average division rate, $\mu$, for each species and $24 \mathrm{~h}$ cycle was estimated according 250 to the equation of Carpenter and Chang (1988):

$$
\mu=\frac{1}{n\left(T_{c}+T_{r}\right)} \sum_{i=1}^{n}\left(t_{s}\right)_{i} \ln \left[1+f_{c}\left(t_{i}\right)+f_{r}\left(t_{i}\right)\right]
$$

252 The "maximum frequency approach" (McDuff and Chisholm, 1982) was applied to 253 estimate the lower bound of the division rate $\left(\mu_{\min }\right)$. The latter is a minimum estimate of the 254 division rate and will approach the true value of $\mu$ only with specific conditions (i.e., when 255 a population has very synchronised division, and it is possible to identify all the dividing or 256 recently divided cells in a single sample).

257

$258 \quad$ 2.6. Lipophilic toxin analysis

259 Lipophilic toxins were extracted from the filters by sonication with a Branson Sonic Power 260250 sonifier (Danbury, CT, USA) as described in Álvarez et al. (2016). To analyse free 261 okadaic acid (OA) and other lipophilic toxins, $0.5 \mathrm{~mL}$ aliquots were placed in amber vials 262 and stored at $-20^{\circ} \mathrm{C}$ until analysis. For the detection of esterified OA-group toxins, $0.5 \mathrm{~mL}$ 263 aliquots were subjected to alkaline hydrolysis following the standard procedure of the EU 264 Reference Laboratory for Marine Biotoxins (EURLMB, 2015). Phytoplankton toxins 265 analysis was carried out according to Regueiro et al. (2011) with minor modifications (a 
shorter column and allowing enough time for the elution of all the toxins) with a Dionex

267 Ultimate 3000 UHPLC system (Thermo Fisher Scientific, Sunnyvale, CA, USA). Toxins

268 detection was carried out with a high-resolution mass spectrometer Q Exactive Focus

269 equipped with an electrospray interphase HESI II (Thermo Fisher Scientific, Sunnyvale,

270 CA, USA) (Table S1). The presence of lipophilic toxins was confirmed by comparing the

271 retention time, exact mass and fragmentation spectra with those of certified reference

272 solutions from the National Research Council (NRC, Halifax Canada). Toxins were

273 quantified by comparing the area of the peaks obtained in the chromatograms with those of

274 the certified reference materials. The detection (LOD) and quantification (LOQ) limits of

275 the LC-MS/MS method were $1.73 \mathrm{ng} \mathrm{mL}^{-1}$ and $3.82 \mathrm{ng} \mathrm{mL}^{-1}$ respectively, for OA, $1.67 \mathrm{ng}$

$276 \mathrm{~mL}^{-1}$ and $2.93 \mathrm{ng} \mathrm{mL}^{-1}$ for DTX-1, and $0.82 \mathrm{ng} \mathrm{mL}^{-1}$ and $1.90 \mathrm{ng} \mathrm{mL}^{-1}$ for PTX-2.

277

278 2.7. Data analysis

279 Data of Dinophysis and ciliate cell densities were $\log$ transformed $(\ln (\mathrm{x}+1))$ to reduce the 280 effect of dominant species. Environmental variables were standardized as in Alves-de281 Souza et al. (2017), to values between 0 and 1, based on the minimum and maximum 282 values of each variable. Statistical analyses were made using ade4 and vegan packages of 283 the free CRAN repository from $\mathrm{R}$ software (R Core Team, 2019). All data were graphed 284 using the Ocean Data View software (Schlitzer, 2019).

286 2.7.1. Niche analysis

287 Data were sorted into two matrices. The first contained biological variables: cell densities 288 of D. acuta, D. acuminata and their potential prey (plastid-retaining ciliates); the second, 
the environmental variables: water temperature, salinity, turbulence, PAR, and sampling

290 depths.

291 An Outlying Mean Index (OMI) analysis was used to characterize the niche position and

292 breadth of D. acuta and D. acuminata (Dolédec et al., 2000). The analysis was performed 293 using the function 'niche' in the ade4 package (Dray and Dufour, 2007). This function uses 294 the centred and scaled environmental dataset, and the ln-transformed matrix containing the 295 cell densities of taxonomic units. The OMI analysis is an ordination technique designed to 296 explicitly take into account the ecological niche of each species within a community, by 297 determining the marginality of a given species (Dolédec et al., 2000). The marginality 298 (OMI parameter) of a species corresponds to its realized niche position in an $n$-dimensional 299 space; OMI analysis seeks the combinations of environmental variables that maximize, for 300 the entire community, each species' marginality. The OMI parameter is defined as the 301 squared Euclidean distance between the mean habitat conditions used by a species and the 302 mean habitat conditions of the sampling domain, the latter defined on a temporal or spatial 303 scale (Hernández-Fariñas et al., 2015; Karasiewicz et al., 2017). In other words, the OMI 304 parameter is defined as the distance between the species niche position and the mean 305 environmental conditions which is also the average habitat used by the community (the 306 origin of the Euclidean space $G$ ). Species with high/low marginality values occur in 307 uncommon/common habitats respectively (Dolédec et al., 2000; Hernández-Fariñas et al., 308 2015). The total inertia (proportional to the average marginality of species), quantifies the 309 influence of the environmental variables on the niche separation of the species (Dolédec et 310 al., 2000).

311 The OMI analysis gives information on species niche breadth with the tolerance parameter 312 (Tol). High and low tolerance values are associated with taxa which occur in wide ranges 
313 (i.e., generalists), and limited ranges (i.e., specialist) of environmental conditions 314 respectively (Karasiewicz et al., 2017). Finally, the residual tolerance (RTol) quantifies the 315 information lost after dimensional reduction. This parameter assesses the reliability of the 316 environmental variables used to define the species niche (Dolédec et al., 2000; Karasiewicz 317 et al., 2017).

318 The statistical significance of the OMI analysis was tested using Monte Carlo permutations 319 included in the packages 'ade4' (10,000 permutations) (Alves-de-Souza et al., 2019; 320 Karasiewicz et al., 2017). The test compares the observed species' marginality and the 321 simulated values, under the null hypothesis that each species is indifferent to its 322 environment (Dolédec et al., 2000).

323 To identify the relevance of the environmental variables (i.e., depth, temperature, salinity, 324 turbulence, PAR, and the cell density of different ciliates) for D. acuta and D. acuminata, a 325 marginal Permutational Analysis of Variance (PERMANOVA) based on Euclidean 326 distances was performed (Anderson, 2014). The analysis estimates an empirical (pseudo) $327 \quad F$-value for each term using 10,000 permutations, to test an association null hypothesis 328 between the Dinophysis species and environmental variables. The analysis was executed 329 with the function adonis2 from the package 'vegan' (Oksanen et al., 2018) using the 330 statistical and programming software R (R Core Team, 2019).

\section{3. Results}

\section{3.1. Oceanographic conditions}

334 Oceanographic conditions during the $48 \mathrm{~h}$ sampling at a fixed station showed the 335 characteristic layering of the fjord described by Pérez-Santos et al. (2014) with an 336 intermittent temperature reversal at the surface. This layering is favoured by riverine 
337 outflow of cold freshwater that was particularly high in the spring preceding this study (Fig.

338 2). Diurnal temperature variability in the upper $3 \mathrm{~m}$ ranged between 16 and $18{ }^{\circ} \mathrm{C}$. This

339 variability was clearly linked to the daily solar heating, from 7:30 to 20:40, and formation

340 of a diurnal thermocline. Strong thermal gradients in the upper $10 \mathrm{~m}$ (from 18 to $14^{\circ} \mathrm{C}$ )

341 were maximal $\left(0.5{ }^{\circ} \mathrm{C} \mathrm{m}^{-1}\right)$ between 6 and $10 \mathrm{~m}$. From 10 to $20 \mathrm{~m}$, temperatures dropped

342 from 14 to $10{ }^{\circ} \mathrm{C}$ (Fig. 2A). Salinity values confirmed (according to the classification in

343 Pérez-Santos et al. (2014)), the presence of Estuarine Fresh Water (EFW, 17.3 to 21) on the

344 surface (0-4 m), Estuarine Salty Water (ESW, 21.19 to 31) below the EFW down to $15 \mathrm{~m}$

345 with a maximal salinity gradient between 5 and $8 \mathrm{~m}$, and Modified Subantarctic Water

346 (MSAAW, 31 to 33), with more uniform salinity, from 15 to $20 \mathrm{~m}$ (Fig. 2B). Strong

347 stratification in the upper $10 \mathrm{~m}$ was associated with high values of the Brunt-Väisälä

348 frequency that were maximal $\left(60-90\right.$ cycles $\left.^{-1}\right)$ in the inter-phase between the EFW and

349 the ESW (4 to $8 \mathrm{~m}$ ) (Fig. 2C). Photosynthetically active radiation (PAR) was maximal (

$3501000 \mu \mathrm{mol} \mathrm{m}^{-2} \mathrm{~s}^{-1}$ ) the second day between 0 and $5 \mathrm{~m}$ from 11:00 to 16:00 h (Fig. 2D).

351 There were no relevant changes in the vertical distributions of inorganic nutrients, at the

352 beginning, mid-point and end of the study. Silicate concentration, with a maximum (> 8

$\left.353 \mu \mathrm{mol} \mathrm{L}{ }^{-1}\right)$ at the surface $(0-2 \mathrm{~m})$ from the river input, dropped between 5 and $10 \mathrm{~m}$ and

354 increased again below $15 \mathrm{~m}$. Nitrate and phosphate concentrations gradually increased with

355 depth, with maximum values of 15 and $2 \mu \mathrm{mol} \mathrm{L}^{-1}$, respectively, in the subsurface layer (15

$356-20 \mathrm{~m})$. The highest nitrite concentrations $\left(0.7-1.0 \mu \mathrm{mol} \mathrm{L}{ }^{-1}\right)$ were detected between 5 and

$35715 \mathrm{~m}$ (Fig. 3). 
360 High cell densities of D. acuta and D. acuminata were mainly restricted to the upper layer

$361(0-10 \mathrm{~m})$, although populations of the two species were vertically segregated (Fig. 4B, C).

362 Dinophysis acuta maximum $\left(7.3 \times 10^{3}\right.$ cells $\left.\mathrm{L}^{-1}\right)$ was detected at $4 \mathrm{~m}$, at 18:00 h on 26

363 February (Fig. 4B), i.e., at the depth where the salinity gradient (in the interface between

364 EFW and ESW) and the Brunt-Väisälä frequency (Fig. 2C) were maximal. During the first

$36524 \mathrm{~h}$, D. acuta migrated vertically (DVM) between 4 and $8 \mathrm{~m}$, with the maximum closer to

366 the surface at night (Fig. 4B). This DVM was different from the tidal signal during this

367 time period (Fig. 4A). Between 16:00 h on February 27 and 2:00 h on February 28, D.

368 acuta densities declined abruptly. This decline coincided with changes in the water column

369 structure and increased turbulence $\left(\varepsilon<10^{-6} \mathrm{~m}^{2} \mathrm{~s}^{-3}\right)$. Numbers increased again from 2:00 h

370 onwards, after the water column structure returned to the previous conditions, with

371 maximal cell numbers at the depth of maximal density gradient.

372 In contrast, D. acuminata, was detected in very low numbers during the first $24 \mathrm{~h}$, but much

373 higher values appeared at the surface $(0-2 \mathrm{~m})$, between 20:00 $\mathrm{h}$ and 00:00 $\mathrm{h}$ the second

374 day, coinciding with the $D$. acuta decline; it reached a maximum of $6.8 \times 10^{3}$ cells L $^{-1}$ (Fig.

375 4C) in an almost isothermal $\left(18^{\circ} \mathrm{C}\right)$ surface layer (Fig. 4B, C, E) at flood tide (Fig. 4A, C).

376 Plots of D. acuta and D. acuminata numbers on potential temperature-salinity (T-S)

377 diagrams were significantly different (Fig. 5). High densities (> $3 \times 10^{3}$ cells $\mathrm{L}^{-1}$ ) of $D$.

378 acuta were found in the ESW water layer with a temperature range of 12.9 to $16.6^{\circ} \mathrm{C}$ and

379 salinity $21.0-28.4$, corresponding to $\sigma \Theta$ values of 15 to 20 . The cell maximum $\left(>7 \times 10^{3}\right.$

380 cells $\left.\mathrm{L}^{-1}\right)$ was found within much narrower ranges of temperature $\left(15.4-16.4^{\circ} \mathrm{C}\right)$ and 
381

382

383

384

385

386

387

388

389

390

391

392

393

394

395

396

397

398

399

400

401

402

salinity (22.9-25.4) (Fig. 5A). High densities of D. acuminata, (> $3 \times 10^{3}$ cells $\mathrm{L}^{-1}$ ) were associated with the surface $\mathrm{EFW}$ water, with a temperature range of 16.1 to $16.5^{\circ} \mathrm{C}$ and salinity 17.4 to 20.0 . The cell maximum $\left(6.8 \times 10^{3}\right.$ cells $\left.\mathrm{L}^{-1}\right)$ was recorded at $16.2^{\circ} \mathrm{C}$ and salinity 17.4. Thus, high cell densities of D. acuminata were associated with less dense water ( $\sigma \Theta$ values between 12.5 and 15 ) than those where D. acuta maxima were found (Fig. $5 B)$.

\subsubsection{Distribution of Mesodinium and other potential ciliate prey}

Mesodinium species, potential prey of Dinophysis, were the dominant microplanktonic ciliates throughout the $48 \mathrm{~h}$ sampling. Maximum densities $\left(9 \times 10^{3}\right.$ cells $\left.\mathrm{L}^{-1}\right)$ occurred in the surface layer $(0-2 \mathrm{~m})$ between 20:00 $\mathrm{h}$ and 22:00 $\mathrm{h}$ during the second day of the study (Fig. 4D), coinciding with those of D. acuminata (Figs. 4B-D). In contrast, there was no overlap between Mesodinium and D. acuta cell maxima.

Other plastid-retaining ciliates, such as Laboea sp., Strombidium spp., Leegaardiella spp., Cyrtostrombidium spp., Paratontonia spp., Pseudotontonia sp. and Lohmanniella sp., were detected, and some of them (e.g., Lohmanniella sp.) in high densities (Fig. 6; Table S2). There were relevant differences between the distributions of these ciliates and those of $D$. acuta and D. acuminata. However, there were some overlaps of Dinophysis with potential alternative ciliate prey. For example, D. acuta maxima coincided with high densities (> 500 cells $\mathrm{L}^{-1}$ ) of Pseudotontonia sp. between 2 and $8 \mathrm{~m}$ from 12:00 to 20:00 h in the first $24 \mathrm{~h}$ (Fig. 4B and Fig. 6C), and with Paratontonia spp. in the upper $6 \mathrm{~m}$ from 8:00 to 12:00 h the second day (Fig. 4B and Fig. 6F). Cell maxima (> 800 cells $\mathrm{L}^{-1}$ ) of Strombidium spp. 
403

404

405

406

407

408

409

410

411

412

413

414

415

416

417

418

419

420

421

422

423

424 Vertical profiles of $\left(\mu_{\min }\right)_{z}$ (i.e., $\mu_{\min }$ at specific depths) at 10:00 h on February 27 and 28

425 showed that the maximal estimate of $\mu_{\min }$ for each Dinophysis species was located at 426

coincided with those of $D$. acuminata in the upper $5 \mathrm{~m}$, from 16:00 to 4:00 $\mathrm{h}$ the second day (Fig. 4C and Fig. 6B).

\subsection{Physiological status of Dinophysis cells}

Both species of Dinophysis exhibited high division rates $\left(\mu>0.5 \mathrm{~d}^{-1}\right)$ during the $48 \mathrm{~h}$ study, but their phased-cell division was not very synchronized. Division in both species began at dawn $(6: 00 \mathrm{~h})$ and lasted until 14:00 h. Total frequency of mitotic cells did not show a single peak, with the exception of the cell cycle of $D$. acuta the first $24 \mathrm{~h}$ (Fig. 7).

The frequencies of dividing $\left(f_{c}\right)$ and recently divided $\left(f_{r}\right)$ cells of $D$. acuta revealed phased cell division on February 27; $f_{c}$ and $f_{r}$ maxima, less than $1 \mathrm{~h}$ apart, formed sharp peaks at 11:00 h, $5 \mathrm{~h}$ after sunrise (Fig 7A). Results were quite different the next day (February 28). There were two $f_{c}$ peaks (at 8:00 $\mathrm{h}$ and 11:00 h); the $f_{r}$ maximum was very close $(<1 \mathrm{~h})$ to the first peak. Estimates of $\mu$ and $\mu_{\min }$ were $0.57 \mathrm{~d}^{-1}$ and $0.45 \mathrm{~d}^{-1}$ on February 27 and $0.76 \mathrm{~d}^{-1}$ and $0.50 \mathrm{~d}^{-1}$ on February 28, respectively.

An $f_{c}$ maximum of $D$. acuminata occurred at 10:00 h on February 27, one hour earlier than that in $D$. acuta; there were two smaller $f_{c}$ peaks, one two hours earlier (at 8:00 h), the second two hours after (at 12:00 h) the maximum. Values of $f_{r}$ had a similar pattern, with a first peak at 8:00 h, $3 \mathrm{~h}$ before the maximum at 11:00 h (Fig. 7B). The next day, $f_{c}$ values formed a plateau from 8:00 to 12:00 h. The maximum value of $f_{r}$ was at 8:00 $\mathrm{h}$ on the two sampling days. Estimates of $\mu$ and $\mu_{\min }$ were $0.49 \mathrm{~d}^{-1}$ and $0.28 \mathrm{~d}^{-1}$ on February 27 , and 0.54 $\mathrm{d}^{-1}$ and $0.30 \mathrm{~d}^{-1}$ on February 28, respectively (Fig. 7B).

different depths within the pycnocline region (Fig. 8). For D. acuta, values of $0.39 \mathrm{~d}^{-1}$ and 
$4270.34 \mathrm{~d}^{-1}$ co-occurred with cell maxima of $6.3 \times 10^{3}$ and $6.7 \times 10^{3}$ cells $\mathrm{L}^{-1}$, respectively on 428 the two days, located in mid-pycnocline $(6 \mathrm{~m})$, forming a well-defined thin layer the second 429 day (Fig. 8 A, B, E). Moderate densities of D. acuminata (maxima $<10^{3}$ cells $\mathrm{L}^{-1}$ first day 430 and $1.1 \times 10^{3}$ cells $\mathrm{L}^{-1}$ second day) occurred in the two profiles at 10:00, with a cell 431 maximum the second day at $4 \mathrm{~m}$, at the top of the pycnocline (Fig. $8 \mathrm{~F}$ ); division rates were 432 lower than those of D. acuta, with a maximum of $0.27 \mathrm{~d}^{-1}$ the first day (Fig. $8 \mathrm{C}$ ). Values of $433\left(\mu_{\min }\right)_{z}$ were almost uniform with depth (from 2 to $12 \mathrm{~m}$ ) the second day (maximum of 0.24 $\left.434 \mathrm{~d}^{-1}\right)$; no well-defined thin layer like that of D. acuta was observed (Fig. 8F).

435 Phytoplankton extracts contained diarrhetic toxins (OA, DTX-1) and pectenotoxins (PTX436 2) throughout the sampling period. Concentrations of OA and DTX-1 co-varied, and their 437 vertical distribution, with maximal values at $4 \mathrm{~m}$, paralleled that of $D$. acuta, and were 438 under detection levels at $0 \mathrm{~m}$ (Fig. 9 A-C). Maximal concentrations of PTX-2 at $4 \mathrm{~m}$ and $4398 \mathrm{~m}$ coincided with maximal densities of $D$. acuta, but high values of PTX-2 were also 440 detected at $0 \mathrm{~m}$, from 20:00 to 2:00 $\mathrm{h}$ the second day, when OA and DTX-1 were almost 441 zero. This PTX-2 maximum at 00:00, was associated with high values (4-7 x $10^{3}$ cells $\mathrm{L}^{-1}$ ) 442 and an overwhelming dominance of D. acuminata (e.g., 84\% at 00:00 and 96\% at 2:00 on 443 the 2 m samples, Fig. 9A).

445 3.4. Niche analysis

446 The OMI analysis (Table 1) showed that the two species of Dinophysis, their putative prey 447 (Mesodinium spp.) and other potential alternative ciliate prey, had significant realized 448 niches $(p<0.01)$. The physical variables included in the analysis had significant influences 449 on most (8 out of 10$)$ of the species included. 
The first and second axis of the OMI ordination (PC1 and PC2) encompassed 82.24\%

451 (OMI1: 63.88\% and OMI2: 18.36\%) of the total projected inertia (Fig. 10A). The OMI

452 plane was defined by two diagonal gradients, each one with inversely correlated variables

453 (Fig. 10B). The first gradient was characterized by Depth - Temperature from the top-left

454 (cold deep water) to the bottom-right (warm and shallow water) of the plan. The second

455 gradient was characterized by Salinity - Turbulence - PAR from the bottom-right (saltier

456 water with lower turbulence and light intensity) to the top-left (fresher estuarine waters

457 with higher turbulence and light intensity) of the plan. The PERMANOVA analysis for

458 Dinophysis species and physical parameters (depth, temperature, salinity, turbulence, and

459 PAR), showed that temperature, salinity and PAR were the significant variables $(p<0.05)$

460 that contributed to most of the explained variability of Dinophysis species. In addition, 461 turbulence had a $p$-value $=0.08$ (Table 2 ).

462 Most of the species were distributed along the Depth - Temperature gradient (Fig. 10B).

463 The OMI analysis showed that the niches of the two Dinophysis species and most of the

464 ciliates, were characterized by habitat preferences (sensu ter Braak and Verdonschot 1995)

465 for upper layers of the water column, but they differed from each other in salinity, 466 temperature, turbulence and PAR preferences. The niches of the two Dinophysis species

467 were quite distinct. That of $D$. acuta was mainly defined by sub-surface waters, influenced 468 by relatively high temperatures, low salinity, and a tendency to avoid conditions of higher 469 turbulence and PAR. On the other hand, the niche of D. acuminata was located in more 470 variable estuarine surface waters with higher turbulence and PAR (Fig. 10B). In addition, 471 D. acuta had a lower marginality value $(\mathrm{OMI}=0.65)$ than $D$. acuminata $(\mathrm{OMI}=1.83)$, due to 472 its wider distribution in the water column during the sampling period. Nevertheless, $D$. 473 acuminata showed a higher tolerance value (Tol=1.90) than D. acuta (Tol= 1.49), 
474 indicating that the realized niche breadth of $D$. acuta was narrower than that of $D$.

475 acuminata (Table 1, Fig. 10C). Mesodinium (Dinophysis potential prey), had a low 476 marginality $(\mathrm{OMI}=0.10)$ and a very high niche breath $(\mathrm{Tol}=3.11)$, indicating that it could be 477 present through the habitat occupied by the two species of Dinophysis (Table 1, Fig. 10C). 478 Finally, PERMANOVA analysis of Dinophysis species and the plastid-retaining ciliates 479 included in the OMI analysis revealed that Mesodinium spp., Pseudotontonia sp. and 480 Strombidium spp., were significant factors explaining Dinophysis species abundance (Table 481 S3).

\section{Discussion}

484 During late summer (February) 2019, actively dividing populations of Dinophysis 485 acuminata and D. acuta co-occurred in PF. The co-occurrence of the two species brought a unique opportunity to study their microscale distribution, behaviour, and potential alternative ciliate prey. The main objective of the study was to elucidate how two species expected to consume the same prey (the ciliate Mesodinium) could thrive blooming at the same time and place. High vertical resolution physical measurements and biological observations during an intensive $48 \mathrm{~h}$ cell cycle study at a fixed station in PF were analysed

491 with a realized niche (sensu Hutchinson 1957) approach. These results showed that the spatial and temporal distribution of the two Dinophysis species, as well as their cell cycle, responded differently to the environmental conditions and prey availability. In other words,

494 the niches of the two species were spatially and temporally differentiated. These results will 495 help to identify environmental conditions favouring bloom development of D. acuta and D. 496 acuminata in the Chilean fjords. In addition, the two species maxima were associated with 497 distinct toxin profiles: the profile of D. acuta was dominated by diarrhetic toxins, and that 
of D. acuminata only with pectenotoxins. These two profiles have distinct impacts on seafood safety management of commercial shellfish species in Chile (Blanco et al., 2018).

\subsection{Vertical distribution of Dinophysis species}

This study showed the co-occurrence of bloom $\left(>10^{3}\right.$ cells $\left.\mathrm{L}^{-1}\right)$ densities of D. acuta and D. acuminata, during $48 \mathrm{~h}$ sampling, but with differences in their vertical distributions. High densities (> $3 \times 10^{3}$ cells $\mathrm{L}^{-1}$ ) of $D$. acuta were found between 4 and $8 \mathrm{~m}$ in the pycnocline (Fig. 4B), while those of D. acuminata were found in the upper $2 \mathrm{~m}$ (Fig. 4C). Studies in Spain and Portugal have shown that when D. acuminata and D. acuta co-occurred, their cell maxima were in water layers with different properties (Escalera et al., 2010; Palma, 1998; Reguera et al., 1993).

Water column stratification has been described as a main factor promoting dinoflagellate bloom development, including Dinophysis blooms (Díaz et al., 2019b; Maestrini, 1998; Reguera et al., 2012; Smayda, 2002). Maximal stratification in PF is observed during spring-summer due to the contribution of the Cisnes River (Calvete and Sobarzo, 2011; Schneider et al., 2014). Our results show strong density gradients, mainly in the top $10 \mathrm{~m}$, where all Dinophysis maxima were found. These gradients (Fig. 2A, B, C) result from the permanent haline stratification of the fjord due to i) high ice-melt in spring from Cisnes River exceeding $1500 \mathrm{~m}^{3} \mathrm{~s}^{-1}$ (http://chonos.ifop.cl/aguadulce/visor) and ii) positive SST anomalies from high insolation in summer 2019. The distributions of the two species suggest differential use of resources determined by their species-specific adaptations, which can be translated into niche differentiation.

The OMI analysis shows that the environmental variables included in the analysis (i.e., depth, temperature, salinity, irradiance PAR and turbulence) can define the niches of the 
522

523

524

525

526

527

528

529

530

531

532

533

534

535

536

537

538

539

540

541

542

543

544 in shallower, more estuarine waters (Fig. 10B). The highest densities of D. acuta occurred 545 in the ESW subsurface layer (15 - 20 isopycnals) and highest values of D. acuminata in the

two Dinophysis species. Their realized niches were characterized by their locations in the upper layers of the water column, but they differed from each other in salinity, temperature, turbulence, and PAR preferences. The OMI marginality results (low for D. acuta and higher for D. acuminata) (Table 1), indicate that these conditions represent the typical habitat of D. acuta, but atypical conditions for D. acuminata (Dolédec et al., 2000). In other words, the environmental conditions were more favourable for D. acuta most of the time, allowing a major occurrence of this species. In addition, it seems that D. acuminata, despite having a broader realized niche breadth than D. acuta (with high OMI and TOL) did not benefit from these conditions, except during the last hours of the study.

Field and laboratory studies have shown that temperature and salinity are relevant oceanographic factors for Dinophysis species in helping to explain their zonation (littoral, neritic, oceanic) and biogeography (cold, temperate, tropical), as well as their distribution in the water column (Maestrini, 1998; Reguera et al., 2014). In the Patagonian channels and fjords (including PF), salinity is the overwhelming property determining seawater density, and water masses are normally described mostly based on salinity values (Pickard, 1971; Sievers and Silva, 2008). Our results demonstrate the fundamental role of temperature in addition to salinity to explain the presence and cell densities of the two Dinophysis species. This is also shown by the OMI and PERMANOVA results. A clear vertical differentiation in the presence of $D$. acuta and D. acuminata was found. This differentiation separates the niches of the two species into water layers with different properties as described in Sievers and Silva (2008). The realized niche of $D$. acuta was mainly defined by the sub-surface more saline waters and a strong influence of temperature, whereas that of D. acuminata was 
EFW surface water (12.5 - 15 isopycnals) (Fig. 5A, B). Observations in this study agree

547 with those from other systems subjected to blooms of $D$. acuminata and $D$. acuta, i.e., $D$.

548 acuminata is found within broader ranges of temperature and salinity than $D$. acuta. The

549 latter is a temperate to cold-temperate species that thrives in frontal areas when

550 temperature-driven stratification is maximal (late summer) (Paterson et al., 2017; Reguera

551 et al., 2014). Nevertheless, it is important to highlight the large intra-specific differences

552 related to the optimal temperature and salinity conditions for growth in different parts of the

553 world. For example, D. acuta blooms in NW Iberia are found in shelf waters with salinities

$554>35$ (Escalera et al., 2010; Moita et al., 2006) but the same species peaks in the Chilean

555 fjords at much lower salinities (15.2) (Díaz et al., 2011). D. acuminata blooms in the Baltic

556 Sea at $7.0^{\circ} \mathrm{C}$ and salinity 6.7 (Hajdu and Larsson, 2006), whereas the same species thrives

557 in the Galician Rias at $15-18{ }^{\circ} \mathrm{C}$ and salinities > 35 (Velo-Suárez et al., 2008). Increased

558 numbers of D. acuta are usually related to years with positive temperature anomalies when

559 more persistent thermal stratification and deeper thermoclines are established (Díaz et al.,

560 2016).

561 Turbulence, a major physical forcing defining phytoplankton abundance and distribution

562 (Margalef, 1978), affects dinoflagellate population dynamics and physiology at the

563 microscale (Berdalet et al., 2017; Sullivan et al., 2003). There is a strong body of

564 information relating dinoflagellates blooms to low turbulence conditions (Glibert, 2016;

565 Margalef, 1978; Smayda and Reynolds, 2001). Díaz et al. (2019c) associated a decline in

566 the division rate of $D$. acuminata with increased turbulence combined with a rapid fall of

567 temperature $\left(>2{ }^{\circ} \mathrm{C}\right)$ during an upwelling event. Laboratory experiments show that $D$.

568 acuta is more sensitive to medium $\left(\varepsilon \approx 10^{-5} \mathrm{~m}^{2} \mathrm{~s}^{-3}\right)$ and high $\left(\varepsilon \approx 10^{-4} \mathrm{~m}^{2} \mathrm{~s}^{-3}\right)$ turbulent

569 mixing than D. acuminata (García-Portela et al., 2019). 
570 The position of D. acuta on the OMI plane suggests that it avoided higher turbulence, while

571 D. acuminata endured more turbulent surface waters (Fig. 10B). Persistent high turbulence

$572\left(\varepsilon \leq 10^{-5} \mathrm{~m}^{2} \mathrm{~s}^{-3}\right)$ on the second night may have caused a dispersion of $D$. acuta, generating a

573 window of opportunity for the more resistant D. acuminata and its prey (Fig. 4B, C). It is

574 important to note that the rise in D. acuminata numbers (from 16:00 h on February 27 to

$5754: 00$ h on February 28) coincided with the replacement of the inverse thermal stratification

576 (colder water at the surface) with an isothermal layer of warmer $\left(18^{\circ} \mathrm{C}\right)$ water in the upper

$5776 \mathrm{~m}$. This rise in temperature may have been partly caused by insolation leading to

578 formation of a diurnal thermocline. Alternatively, the high density population of $D$.

579 acuminata may have been advected from other areas more favourable for growth. This

580 possibility is supported by the coincidence with increased turbulence, and by the fact that

581 high densities (> $5 \times 10^{3}$ cells $\mathrm{L}^{-1}$ ) of $D$. acuminata were found two days before (February

$58224^{\text {th }}$ ) (data not shown) in surface waters $8 \mathrm{~km}$ south of the sampling station at the 583 confluence of Magdalena Sound and PF (Fig. 1C). Predominant southerly winds in summer

584 have been found to force unidirectional northward currents (Pinilla et al., 2020). These

585 observations are compatible with a possible wind-driven advection of the $D$. acuminata 586 population observed the second day, coinciding with flood tide.

587 The association of $D$. acuminata cell maxima with the diurnal thermocline was reported in 588 the Galician Rías (Velo-Suárez et al., 2008). In the same region, Pizarro et al (2008) 589 identified semidiurnal tides as a main factor underlying the diurnal variability of a $D$. acuta 590 bloom at a fixed station. Tides were also identified as a short time scale factor modulating 591 bloom formation of Pseudo-nitzschia species in an upwelling system (Díaz et al., 2014) and 592 D. acuta in Pitipalena, a nearby Chilean fjord (Díaz et al. 2011). 
595 To date, all Dinophysis species in culture have been shown to be obligate mixotrophs that 596 retain plastids (kleptoplastids) from their prey to perform photosynthesis (Hansen et al., 597 2013; Park et al., 2006; Riisgaard and Hansen, 2009). Nevertheless, each species has its 598 own adaptations. Niche position on the OMI plane revealed that D. acuta tended to avoid 599 surface waters $(0-2 \mathrm{~m})$ where light intensity is high, while $D$. acuminata showed a 600 preference for this parameter (Fig. 10B). García-Portela et al. (2018) found that D. acuta 601 was more susceptible to photo-damage when exposed to high light intensities (370 - 650 $602 \mu \mathrm{mol} \mathrm{m} \mathrm{m}^{-2}$ ) in which D. acuminata can survive and grow. In addition, D. acuta was able to 603 survive longer periods in the dark. These differences may explain the co-occurrence of $D$. 604 acuta in subsurface layers (lower light intensity) with D. acuminata at the surface (high 605 light) (García-Portela et al., 2018).

606 Field incubations with $\mathrm{N}^{15}$ labelled compounds in two upwelling areas showed $D$. 607 acuminata preference for ammonia and organic nitrogen sources. Uptake rates of this 608 species led the authors to classify it as a "high affinity strategist", adapted to grow with 609 regenerated nitrogen sources in nutrient-poor environments (Seeyave et al., 2013; Seeyave 610 et al., 2009). These preferences were confirmed in laboratory experiments (Hattenrath611 Lehmann and Gobler 2015). García-Portela et al (2020) showed that neither D. acuminata 612 nor D. acuta take up nitrate. A review of transcriptomic databases showed a paucity of 613 nitrate transporter homologs in D. acuminata. Ammonia measurements were not made in 614 the present study, but scarce (low vertical resolution) ammonia data from Chilean fjords 615 shows concentrations in PF between 0.377 and $1.867 \mu \mathrm{mol} \mathrm{L}{ }^{-1}$ (Gallardo-Carrasco, 2017; 616 Prado-Fiedler, 2000). But nitrogen recycling rates are high and are overlooked in simple 617 measurements of free ammonia. Culture experiments have shown that Dinophysis division 
618 is triggered after ingestion of prey (Nielsen et al., 2012; Smith and Hansen, 2007).

619 Considering the high values of $\mu$ observed in this study and the healthy appearance of the 620 cells, including specimens swollen with digestive vacuoles (Fig. S2), it seems assured that

621 Dinophysis populations in PF were not food-limited.

622 Mesodinium species, mainly M. rubrum, are the only confirmed prey of Dinophysis and 623 source of their kleptoplastids in the field and in laboratory cultures. Likewise, cryptophytes 624 belonging to the Teleaulax/Plagioselmis/Geminigera (TPG) clade are the only known 625 group supporting growth of Mesodinium, which are also kleptoplastidic mixotrophs. These 626 trophic relations have been established in field populations when partial 23S rDNA 627 sequences of Dinophysis plastids match those of Mesodinium and its prey (e.g., Teleaulax 628 amphioxeia) (Rial et al. 2015). Recent observations in the Chilean fjords of Dinophysis 629 apparently feeding on ciliates other than Mesodinium, and the mismatch of their plastid 630 sequences with those of local Mesodinium fuelled the hypothesis of an alternative prey 631 (Díaz et al., 2020a). Furthermore, these authors demonstrated that Dinophysis acuta, D. 632 caudata, D. tripos and D. subcircularis from southern Chile had plastids of cryptophytes 633 belonging to clade V (Rhinomonas/Rhodomonas/Storeatula). That was the first report of 634 Dinophysis species with plastids from a cryptophyte clade other than the TPG clade. But 635 the ciliate prey (vector) transferring clade V cryptophytes plastids to Dinophysis was not 636 identified.

637 Analysis of the accompanying plastid-bearing ciliates in the present $48 \mathrm{~h}$ study did not 638 show any relationship between the daily vertical migration (DVM) of D. acuta and the 639 distribution of Mesodinium spp. (Fig. 4B and D), although D. acuminata and Mesodinium 640 populations coincided at the surface between 20:00 $\mathrm{h}$ and 00:00 $\mathrm{h}$ the second day when 641 both predator and potential prey reached their cell maxima (Fig. 4C, D). It is true that the 
642 643 evidence of a trophic relationship; nevertheless, it gives a clue about ciliates species to be 644 tested in future studies to identify, with molecular tools, alternative prey in the Chilean 645 fjord's region.

646 In the Galician Rías, partial sequences of the plastids 23S rDNA of Dinophysis and 647 Mesodinium species were identical (Rial et al., 2015). During a 2 weeks cruise also in the 648 649 650 651

co-occurrence of ciliates other than Mesodinium species with Dinophysis does not provide Rías, Díaz et al. (2019c) found that cell maxima of D. acuminata and its prey coincided at noon when Mesodinium spp. migrated to the surface. D. acuminata formed a thin layer and did not migrate, but with an angler's strategy waited for its prey to pass by. Similar observations were reported from the Baltic Sea by Sjöqvist and Lindholm (2011). Our results illustrate an overlap of D. acuminata and Mesodinium at night (Fig. 4C and D). Earlier studies concluded that Dinophysis and Mesodinium had distinct niches but cooccurred in the same water masses and eventually met (González-Gil et al., 2010), thus facilitating feeding of D. acuminata on its prey. These observations are compatible with the mucilage secreted in cultures of D. acuta (Papiol et al., 2016) and D. acuminata, which acts as a "mucus trap" and entangles the fast swimming ciliates. The OMI parameter values show that environmental conditions during the $48 \mathrm{~h}$ study were common to both Mesodinium species and D. acuminata. The two organisms share a high niche breadth (Fig. 10C), which allows them a wide distribution in the water column (Fig. 4D).

Other plastid-bearing ciliates described as potential prey co-occurred with Dinophysis in the present study. The PERMANOVA analysis identified Mesodinium spp., Pseudotontonia sp. and Strombidium spp. as significant explanatory factors for the two Dinophysis species (Table S3). However, the present information does not allow us to attribute the $D$. acuta migrations or the distribution of $D$. acuminata to predation on one or 
more of these potential prey. The question remains open pending new information on the

667 plastid sequences of predators and potential prey. The OMI and PERMANOVA analysis

668 results emphasize the importance of the different environmental variables considered here

669 (i.e., abiotic: depth, temperature, salinity, turbulence, and PAR, and biotic: Mesodinium

670 spp. and other potential prey). The PERMANOVA identified temperature, salinity, and

671 PAR as significant factors to explain Dinophysis abundance and distribution (Table 2).

672 It is important to highlight that additional intrinsic factors or traits, such as cell morphology

673 and swimming abilities may contribute to the response of each Dinophysis species to

674 environmental factors. For example, D. acuta is more dorso-ventrally compressed, its

675 volume three times larger and with a higher surface to volume ratio than the more rounded

676 D. acuminata (García-Portela et al., 2018). These features make D. acuta more vulnerable

677 to unstable conditions, such as those in the surface layers and facilitate the success of the

678 more rounded $D$. acuminata in fresher and more illuminated surface waters subject to a

679 wider range of temperature.

680

\subsubsection{In situ division rates}

683 Data on in situ division rates of Dinophysis acuta are scarce. When available, however, it 684 allows to distinguish the contribution of intrinsic population growth from behavioural 685 aggregation and wind driven advection (Farrell et al., 2014; Pizarro et al., 2008; Reguera et 686 al., 2003). The estimate of $\mu\left(0.76 \mathrm{~d}^{-1}\right)$ during the second day of this study, exceeding one 687 doubling per day, is the highest value ever reported in field populations of D. acuta. As in 
earlier studies, the onset of light was the trigger for phased-cell division of D. acuminata; D. acuta division started later, after sunrise (Fig. 7).

Reguera et al. (2003) suggested that the shape of the phase frequency curves show large differences depending on the stage of Dinophysis population growth and the physiological status of the cells. In general, division time $\left(\mathrm{T}_{\mathrm{D}}\right.$, time between peaks of paired and recently divided cells) was shorter, and the frequencies curve had a deeper slope in fit populations with high division rates. Poor synchronization in division could be associated with late phases of population growth (i.e., stationary phase), or be caused by increased cell numbers due to physical accumulation or behaviour. The latter could have been the case of a stationary phase population advected to the Galician Rías (Pizarro et al 2008). But $\mathrm{T}_{\mathrm{D}}$ in the present study was extremely short (less than $1 \mathrm{~h}$ ) in both species, and with the exception of the first cycle of D. acuta, frequency distributions looked like the overlapping of two consecutive divisions (Fig. 7A, B). In any case, the high values of $\mu$ and the fact that the maximal values of $\mu_{\min }$ were observed at the same depth as the cell maximum (Fig. 8), confirmed that active growth (higher in the case of D. acuta) contributed to the high numbers observed for the two species during the $48 \mathrm{~h}$ study in PF. The exception was the homogeneous vertical distribution of $\mu_{\min }$ in $D$. acuminata the second day (28 Feb). It is possible that this lack of layering was due to recent transport of cells.

\section{anc}


712 species at $0 \mathrm{~m}$ with a cell maximum at this depth during a short time window, on the second 713 day. This coincided with a clear PTX-2 peak. Unambiguous identification of species714 specific toxin profiles in field populations of Dinophysis requires LC-MS analysis of 715 individually picked cells, as in Pizarro et al. (2013), or of unialgal cultures. So far, cultures 716 of Dinophysis have not been established in Chile, but analyses of picked cells of $D$. cf 717 acuminata from the north (Coquimbo) (Blanco et al., 2007) and south (Los Lagos) (Fux et 718 719 720 721 722 723 724 725 726 727 728 729 730

30

al. 2011; Blanco et al 2018) provinces have been made. In all these cases, PTX-2 was the only toxin detected by LC-MS. PTX-2 was also the only toxin detected in plankton concentrates from Reloncaví (Los Lagos) rich in D. acuminata (Alves-de-Souza et al., 2014). More recently, PTX-2 was the only toxin reported in shellfish (Tagelus dombeii) exposed to an intense spring bloom of D. acuminata on the central Chilean coast (Díaz et al., 2020b). These results support the suspicion that the two diarrhetic toxins found during the present study were both produced by $D$. acuta. and that at least in this region, $D$. acuta is the main source of diarrhetic shellfish toxins. Since PTX-2 is not diarrheogenic by oral administration, and pectenotoxins have been deregulated in some countries, these differences in toxin profiles have an important impact on shellfish safety management. Pending final confirmation, D. acuta is thus the species suspected of being the main cause of DSP toxin (OA + DTXs) accumulation in shellfish in Southern Chile.

\subsubsection{Diurnal Vertical Migration}

D. acuta migrated (DVM) from $8 \mathrm{~m}$ during the day to $4 \mathrm{~m}$ at night, more clearly in the first $24 \mathrm{~h}$ (Fig. 4B). This DVM had a similar short range but different pattern to that observed during a bloom of D. acuta in Big Glory Bay (Steward Island, New Zealand), 
735 with maxima at $15 \mathrm{~m}$ from 1:00 to 7:00, and at $10 \mathrm{~m}$ from 7:00 until the end of the study 736 at 22:00 (MacKenzie 1992). D. acuminata did not exhibit clear DVM, and cell maxima 737 were in the upper $2 \mathrm{~m}$. There was no evidence of migration at all in the latter species in 738 some studies in the Galician Rías (Díaz et al., 2019c; Velo-Suárez et al., 2008). In 739 contrast, Villarino et al. (1995) described DVM of D. acuminata, from the surface $740(1.25 \mathrm{~m})$ during the first hours of light, to $\sim 10 \mathrm{~m}$ during the evening and night in Ría of 741 Vigo, also in the Galician Rías (NW Spain); this movement coincided with the DVM of 742 co-occurring dinoflagellates and of Mesodinium, and took place under extremely calm 743 conditions in thermally stratified waters in late summer (August). At the time, it was still 744 unknown that Mesodinium was a Dinophysis prey, and its migration was related to light 745 uptake during the day at the surface, and nutrient uptake at night in deeper waters. It is 746 well known that dinoflagellates can have distinct DVM patterns at different stages of 747 population growth or in response to the availability of resources, such as light, nutrients 748 and prey (Ross and Sharples, 2007). The position of the D. acuta maximum, coincident 749 with the vertical distribution of $\mathrm{OA}\left(117.6 \mathrm{ng} \mathrm{OA} \mathrm{mL}^{-1}\right.$ ) (Fig. 9A), had no apparent 750 relation with tidal phase, but migration to upper layers at night could be related to prey 751 searching. In contrast, D. acuminata aggregations at the surface may have been using the 752 angler's strategy already described, to intercept Mesodinium cells during their morning 753 migration to the most illuminated surface layers (Díaz et al., 2019c; Sjöqvist and 754 Lindholm, 2011). A model from Yamazaki and Kamykowski (1991) predicts that cells 755 within a migrating population exposed to wind-induced vertical mixing do not migrate 756 uniformly but scatter within the mixed layer. A similar model might explain the even 757 vertical distribution of $D$. acuminata division rates at depth $\left(\mu_{\min }\right)_{z}$ the second day (Fig. 758 8). 


\section{Conclusions}

760 This is the first time high vertical resolution hydrodynamic measurements including

761 turbulence, have been made during intensive sampling of co-occurring blooms of D. acuta,

762 D. acuminata and plastid bearing micro-ciliates in a stratified fjord system. Populations of

763 the two Dinophysis species, in particular D. acuta, had very high division rates $\left(\mu>0.6 \mathrm{~d}^{-1}\right)$

764 and the depth of their respective cell density and division rate maxima coincided.

765 Therefore, bloom densities resulted from a combination of intrinsic growth rate and

766 physical factors which favoured niche differentiation of the two Dinophysis species. A

767 realized niche approach (with an Outlying Mean Index analysis) applied to results from the

$76848 \mathrm{~h}$ study provided the opportunity to identify different environmental conditions defining

769 these niches. The realized niche of $D$. acuta, was mainly defined by sub surface saltier

770 waters with a strong influence of temperature, and avoidance of more turbulent and

771 illuminated conditions at the surface. The realized niche of $D$. acuminata was characterized

772 by estuarine surface waters with warmer temperatures and higher turbulence and light

773 intensity. The apparent relationship between the ciliate Mesodinium and the distribution of

774 D. acuminata, but not with $D$. acuta, is compatible with hypothesis on alternative plastid-

775 retaining ciliate prey for Dinophysis. Cell maximum of D. acuta was associated with peaks

776 of DSP toxins (OA + DTX-1) and PTX-2. In contrast, only PTX-2 was found in detectable

777 amounts associated with a dense D. acuminata patch where this species represented $>96 \%$

778 of the total number of Dinophysis. These observations suggest (awaiting confirmation by

779 picked cell analyses) that D. acuta is the main source of DSP toxins in Southern Chile,

780 whereas D. acuminata appears related only to PTX-2. Field concentrations of Dinophysis

781 may be over one order of magnitude higher than estimates from water column integrated

782 hose samples collected in the official monitoring programme. Results from this study 
improve current knowledge on conditions promoting blooms of two species of Dinophysis with distinct impacts on aquaculture resources.

\section{Acknowledgements}

This work was funded by ANID-FONDECYT 11170682 from the National Agency of Research and Development (ANID), Chile, and by projects REDES170101 and REDI170575 from ANID International Cooperation Programme. C. F-P. was supported by grant IN607A 2018/2 from the Axencia Galega de Innovación (Galicia, Spain); I. P-S. by COPAS Sur-Austral AFB170006 and CIEP R20F002; F.B. by ANID-FONDECYT 3180307 and B. R by EU - Interreg Atlantic Area project PRIMROSE (EAPA_182/2016). A. M. B. had a Ph.D student fellowship from Universidad de Los Lagos. We thank A. Bode from IEO, Centro Oceanográfico de A Coruña, Spain, for valuable comments.

\section{References}

Álvarez, G., Uribe, E., Regueiro, J., Blanco, J., Fraga, S., 2016. Gonyaulax taylorii, a new yessotoxins-producer dinoflagellate species from Chilean waters. Harmful Algae $58,8-15$.

Alves-de-Souza, C., Benevides, T.S., Santos, J.B., Von Dassow, P., Guillou, L., Menezes, M., 2017. Does environmental heterogeneity explain temporal $\beta$ diversity of small eukaryotic phytoplankton? Example from a tropical eutrophic coastal lagoon. J. Plankton Res. 39 (4), 698-714.

Alves-de-Souza, C., Iriarte, J.L., Mardones, J.I., 2019. Interannual variability of Dinophysis acuminata and Protoceratium reticulatum in a Chilean Fjord: Insights from the realized niche analysis. Toxins $11(1), 19$. 
Alves-de-Souza, C., Varela, D., Contreras, C., de La Iglesia, P., Fernández, P., Hipp, B., Hernández, C., Riobó, P., Reguera, B., Franco, J.M., 2014. Seasonal variability of Dinophysis spp. and Protoceratium reticulatum associated to lipophilic shellfish toxins in a strongly stratified Chilean fjord. Deep-Sea Res. Pt. II. 101, 152-162.

Anderson, M.J., 2014. Permutational multivariate analysis of variance (PERMANOVA). Wiley statsref: statistics reference online, 1-15.

Avaria, S., 2008. Phytoplankton in the austral Chilean channels and fjords. In: N. Silva \& S. Palma (eds). Progress in the oceanographic knowledge of Chilean interior waters, from Puerto Montt to Cape Horn. Comité Oceanográfico Nacional - Pontificia Universidad Católica de Valparaíso, Valparaíso, 89-92.

Berdalet, E., Montresor, M., Reguera, B., Roy, S., Yamazaki, H., Cembella, A., Raine, R., 2017. Harmful algal blooms in fjords, coastal embayments, and stratified systems: recent progress and future research. Oceanography 30 (1), 46-57.

Blanco, J., Álvarez, G., Rengel, J., Díaz, R., Mariño, C., Martín, H., Uribe, E., 2018. Accumulation and biotransformation of Dinophysis toxins by the surf clam Mesodesma donacium. Toxins 10 (8), 314.

Blanco, J., Álvarez, G., Uribe, E., 2007. Identification of pectenotoxins in plankton, filter feeders, and isolated cells of Dinophysis acuminata with an atypical toxin profile, from Chile. Toxicon 49 (5), 710-716.

Brun, P., Vogt, M., Payne, M.R., Gruber, N., O'Brien, C.J., Buitenhuis, E.T., Le Quéré, C., Leblanc, K., Luo, Y.W., 2015. Ecological niches of open ocean phytoplankton taxa. Limnol. Oceanogr. 60 (3), 1020-1038. 
829 Calvete, C., Sobarzo, M., 2011. Quantification of the surface brackish water layer and

830 frontal zones in southern Chilean fjords between Boca del Guafo $\left(43^{\circ} 30^{\prime} \mathrm{S}\right)$ and

$831 \quad$ Estero Elefantes (46³0' S). Cont. Shelf Res. 31 (3-4), 162-171.

832 Carpenter, E.J., Chang, J., 1988. Species-specific phytoplankton growth rates via diel DNA

833 synthesis cycles. 1. Concept of the method. Mar. Ecol. Prog. Ser. 43 (1), 105-111.

834 Cassis, D., Muñoz, P., Avaria, S., 2002. Variación temporal del fitoplancton entre 1993 y

8351998 en una estación fija del seno Aysén, Chile (45²6'S 7300'W). Rev. Biol. Mar.

$836 \quad$ Oceanog. $37(1), 43-65$.

837 Colwell, R.K., Rangel, T.F., 2009. Hutchinson's duality: the once and future niche. Pro.

$838 \quad$ Natl. Acad. Sci. 106 (Supplement 2), 19651-19658.

839 Díaz, P., Fernández-Pena, C., Pérez-Santos, I., Baldrich, A., Díaz, M., Rodríguez, F., 840 2020a. Dinophysis Ehrenberg (Dinophyceae) in Southern Chile harbours red

841 842 cryptophyte plastids from Rhodomonas/Storeatula clade. Harmful Algae 99,

843 Díaz, P., Molinet, C., Cáceres, M.A., Valle-Levinson, A., 2011. Seasonal and intratidal 844 distribution of Dinophysis spp. in a Chilean fjord. Harmful Algae 10 (2), 155-164.

845 Díaz, P.A., Álvarez, A., Varela, D., Pérez-Santos, I., Díaz, M., Molinet, C., Seguel, M., 846 Aguilera-Belmonte, A., Guzmán, L., Uribe, E., Rengel, J., Hernández, C., Segura, 847 848

849 Díaz, P.A., Álvarez, G., Seguel, M., Marín, A., Krock, B., 2020b. First detection of 850 pectenotoxin-2 in shellfish associated with an intense spring bloom of Dinophysis

851 acuminata on the central Chilean coast. Mar. Pollut. Bull. 158, 111414. 
Díaz, P.A., Peréz-Santos, I., Álvarez, G., Garreaud, R., Pinilla, E., Díaz, M., Sandoval, A., Araya, M., Álvarez, F., Rengel, J., Montero, P., Pizarro, G., López, L., Iriarte, L., Igor, G., Reguera, B., 2021. Multiscale physical background to an exceptional harmful algal bloom of Dinophysis acuta in a fjord system. Sci. Total Environ. 773, 145621.

Díaz, P.A., Reguera, B., Moita, T., Bravo, I., Ruiz-Villarreal, M., Fraga, S., 2019b. Mesoscale dynamics and niche segregation of two Dinophysis species in GalicianPortuguese coastal waters. Toxins 11 (1), 37.

Díaz, P.A., Ruiz-Villarreal, M., Mouriño-Carballido, B., Fernández-Pena, C., Riobó, P., Reguera, B., 2019c. Fine scale physical-biological interactions during a shift from relaxation to upwelling with a focus on Dinophysis acuminata and its potential ciliate prey. Prog. Oceanogr. 175, 309-327.

Díaz, P.A., Ruiz-Villarreal, M., Pazos, Y., Moita, T., Reguera, B., 2016. Climate variability and Dinophysis acuta blooms in an upwelling system. Harmful Algae 53, 145-159.

Díaz, P.A., Ruiz-Villarreal, M., Velo-Suárez, L., Ramilo, I., Gentien, P., Lunven, M., Fernand, L., Raine, R., Reguera, B., 2014. Tidal and wind-event variability and the distribution of two groups of Pseudo-nitzschia species in an upwelling-influenced Ría. Deep-Sea Res. Pt. II. 101, 163-179.

Dolédec, S., Chessel, D., Gimaret-Carpentier, C., 2000. Niche separation in community analysis: a new method. Ecology 81 (10), 2914-2927.

Dray, S., Dufour, A.-B., 2007. The ade4 package: implementing the duality diagram for ecologists. J. Stat. Softw. 22 (4), 1-20. 
874 Escalera, L., Reguera, B., Moita, T., Pazos, Y., Cerejo, M., Cabanas, J.M., Ruiz-Villarreal,

875 M., 2010. Bloom dynamics of Dinophysis acuta in an upwelling system: In situ

876 growth versus transport. Harmful Algae 9(3), 312-322.

877 Escalera, L., Reguera, B., Pazos, Y., Moroño, A., Cabanas, J., 2006. Are different species

878

879

880

881

882

883

884

885

886

887

888

889

890

891

892

893

894

Farrell, H., Velo-Suárez, L., Reguera, B., Raine, R., 2014. Phased cell division, specific lipophilic marine biotoxins in mollucs by LC-MS/MS. Version 5, 1-33.

European Commission., 2019. Commission Implementing Regulation (EU) 2019/627 of 15 March 2019 laying down uniform practical arrangements for the performance of official controls on products of animal origin intended for human consumption in accordance with Regulation (EU) 2017/625 of the European Parliament and of the Council and amending Commission Regulation (EC) No 2074/2005 as regards official controls. Off. J. Eur. Union L131, 51.

division rates and other biological observations of Dinophysis populations in subsurface layers off the south coast of Ireland. Deep-Sea Res. Pt. II: Topical Stud. Oceanography 101, 249-254.

Fernández, R., Mamán, L., Jaén, D., Fuentes, L., Ocaña, M.A., Gordillo, M.M., 2019. Dinophysis species and diarrhetic shellfish toxins: 20 years of monitoring program in Andalusia, South of Spain. Toxins 11 (4), 189.

895 Fux, E., Smith, J.L., Tong, M., Guzmán, L., Anderson, D.M., 2011. Toxin profiles of five 896 geographical isolates of Dinophysis spp. from North and South America. Toxicon 57 (2), 275-287. 
Gaillard, S., Le Goïc, N., Malo, F., Boulais, M., Fabioux, C., Zaccagnini, L., Carpentier, L., Sibat, M., Réveillon, D., Séchet, V., 2020. Cultures of Dinophysis sacculus, D. acuminata and pectenotoxin 2 affect gametes and fertilization success of the Pacific oyster, Crassostrea gigas. Environ. Pollut. 265, 114840.

Gallardo-Carrasco, M.P., 2017. ¿Existe una relación entre biomasa fitoplanctónica y concentración de amonio en fiordos patagónicos? Ing. degree Thesis. Universidad Austral de Chile, Puerto Montt-Chile.

García-Portela, M., Reguera, B., Ribera d'Alcalà, M.R., Rodríguez, F., Montresor, M., 2019. Effects of small-scale turbulence on two species of Dinophysis. Harmful Algae 89, 101654.

García-Portela, M., Reguera, B., Gago, J., Gac, M.L., Rodríguez, F., 2020. Uptake of Inorganic and Organic Nitrogen Sources by Dinophysis acuminata and D. acuta. Microorganisms 8 (2), 187.

García-Portela, M., Riobó, P., Reguera, B., Garrido, J.L., Blanco, J., Rodríguez, F., 2018. Comparative ecophysiology of Dinophysis acuminata and D. acuta (Dinophyceae, Dinophysiales): effect of light intensity and quality on growth, cellular toxin content, and photosynthesis. J. Phycol. 54 (6), 899-917.

García, C., González, V., Cornejo, C., Palma-Fleming, H., Lagos, N., 2004. First evidence of Dinophysistoxin-1 ester and carcinogenic polycyclic aromatic hydrocarbons in smoked bivalves collected in the Patagonia fjords. Toxicon 43 (2), 121-131.

GEOHAB, 2008. Global Ecology and Oceanography of Harmful Algal Blooms, GEOHAB Core Research Project: HABs in Stratified Systems. P. Gentien, B. Reguera, H. Yamazaki, L. Fernand, E. Berdalet, and R. Raine (Eds.). IOC and SCOR, Paris, France, and Newark, Delaware, USA. 59pp. 
GEOHAB, 2011. GEOHAB Modelling: A Workshop Report. D.J. McGillicuddy, Jr., P.M. Glibert, E. Berdalet, C. Edwards, P. Franks, and O. Ross (eds). IOC and SCOR, Paris and Newark, Delaware, 85pp.

Gestal-Otero, J.J., 2014. Epidemiology of marine toxins, In: Botana, L.M. (Ed.), Seafood and Freshwater Toxins: Pharmacology, Physiology, and Detection, 3rd ed. CRC Press, Taylor and Francis Group, Boca Ratón, FL, USA. pp. 123-195.

Glibert, P.M., 2016. Margalef revisited: a new phytoplankton mandala incorporating twelve dimensions, including nutritional physiology. Harmful Algae 55, 25-30.

González-Gil, S., Velo-Suárez, L., Gentien, P., Ramilo, I., Reguera, B., 2010. Phytoplankton assemblages and characterization of a Dinophysis acuminata population during an upwelling-downwelling cycle. Aquat. Microb. Ecol. 58 (3), 273-286.

Grasshoff, K., Ehrhardt, M., Kremling, K., 1983. Methods of seawater analysis. Verlag Chemie Weinhein, New York, USA.

Grüner, N., Gebühr, C., Boersma, M., Feudel, U., Wiltshire, K.H., Freund, J.A., 2011. Reconstructing the realized niche of phytoplankton species from environmental data: fitness versus abundance approach. Limnol. Oceanogr. Meth. 9 (10), 432-442.

Hajdu, S., Larsson, U., 2006. Life-cycle stages of Dinophysis acuminata (Dinophyceae) in the Baltic Sea. Afr. J. Mar. Sci. 28 (2), 289-293.

Hansen, P.J., Nielsen, L.T., Johnson, M., Berge, T., Flynn, K.J., 2013. Acquired phototrophy in Mesodinium and Dinophysis - A review of cellular organization, prey selectivity, nutrient uptake and bioenergetics. Harmful Algae 28, 126-139. 
Hattenrath-Lehmann, T., Gobler, C.J., 2015. The contribution of inorganic and organic nutrients to the growth of a North American isolate of the mixotrophic dinoflagellate, Dinophysis acuminata. Limmol. Oceanogr. 60, 1588-1603.

Hernández-Fariñas, T., Bacher, C., Soudant, D., Belin, C., Barillé, L., 2015. Assessing phytoplankton realized niches using a French national phytoplankton monitoring network. Estuar. Coast. Shelf Sci. 159, 15-27.

Holt, R.D., 2009. Bringing the Hutchinsonian niche into the 21 st century: ecological and evolutionary perspectives. Proc. Natl. Acad. Sci. USA. 106 (Supplement 2), 1965919665.

Hutchinson, G., 1957. Concluding remarks. Cold Spring Harbor Symposia on Quantitative biology. $22(2), 415-427$.

Irwin, A.J., Nelles, A.M., Finkel, Z.V., 2012. Phytoplankton niches estimated from field data. Limnol. Oceanogr. 57 (3), 787-797.

Karasiewicz, S., Breton, E., Lefebvre, A., Fariñas, T.H., Lefebvre, S., 2018. Realized niche analysis of phytoplankton communities involving HAB: Phaeocystis spp. as a case study. Harmful Algae 72, 1-13.

Karasiewicz, S., Chapelle, A., Bacher, C., Soudant, D., 2020. Harmful algae niche responses to environmental and community variation along the French coast. Harmful Algae 93, 101785.

Karasiewicz, S., Dolédec, S., Lefebvre, S., 2017. Within outlying mean indexes: refining the OMI analysis for the realized niche decomposition. PeerJ 5, 3364.

Kattner, G., Becker, H., 1991. Nutrients and organic nitrogenous compounds in the marginal ice zone of the Fram Strait. J. Mar. Syst. 2, 385-394. 
967

968

969

970

971

972

973

974

975

976

977

978

979

980

981

982

983

984

985

986

987

988

Kim, M., Kim, S., Yih, W., Park, M.G., 2012. The marine dinoflagellate genus Dinophysis can retain plastids of multiple algal origins at the same time. Harmful Algae 13, 105-111.

Kim, S., Kang, Y.G., Kim, H.S., Yih, W., Coats, D.W., Park, M.G., 2008. Growth and grazing responses of the mixotrophic dinoflagellate Dinophysis acuminata as functions of light intensity and prey concentration. Aquat. Microb. Ecol. 51 (3), 301-310.

Litchman, E., Edwards, K.F., Klausmeier, C.A., Thomas, M.K., 2012. Phytoplankton niches, traits and eco-evolutionary responses to global environmental change. Mar. Ecol. Prog. Ser. 470, 235-248.

Lovegrove, T., 1960. An improved form of sedimentation apparatus for use with an inverted microscope. ICES J. Mar. Sci. 25 (3), 279-284.

Luketina, D.A., Imberger, J., 2001. Determining turbulent kinetic energy dissipation from Batchelor curve fitting. J. Atmos. Ocean. Tech. 18 (1), 100-113.

MacKenzie, L., 1992. Does Dinophysis (Dinophyceae) have a sexual life cycle? J. Phycol. 28(3), 399-406.

Maestrini, S.Y., 1998. Bloom dynamics and ecophysiology of Dinophysis spp., In: D.M. Anderson, A.D. Cembella, and G.M. Hallegraeff (Ed.), Physiological Ecology of Harmful Algal Blooms. NATO ASI Series, Series G, Ecological Science, SpringerVerlag, Berlin, Heidelberg, New York, pp. 243-266.

Margalef, R., 1978. Life-forms of phytoplankton as survival alternatives in an unstable environment. Oceanol. Acta 1 (4), 493-509. 
1008

1009

1010

1011

McDuff, R., Chisholm, S., 1982. The calculation of in situ growth rates of phytoplankton populations from fractions of cells undergoing mitosis: a clarification 1. Limnol. Oceanogr. 27 (4), 783-788.

Moita, M., Sobrinho-Gonçalves, L., Oliveira, P., Palma, S., Falcão, M., 2006. A bloom of Dinophysis acuta in a thin layer off North-West Portugal. Afr. J. Mar. Sci. 28 (2), 265-269.

Munday, R., 2014. Toxicology of seafood toxins: a critical review, In: M.L. Botana (Ed.), Seafood and Freshwater Toxins, Pharmacology, Physiology and Detection. CRC Press, Boca Raton, FL, USA, pp. 197-290.

Muñoz, P., 1992. Presencia de dinoflagelados tóxicos del género Dinophysis en el seno de Aysén, Chile. Rev. Biol. Mar. Valparaiso 27, 187-212.

Nielsen, L.T., Krock, B., Hansen, P.J., 2012. Effects of light and food availability on toxin production, growth and photosynthesis in Dinophysis acuminata. Mar. Ecol. Prog. Ser. $471,37-50$.

Oksanen, J., Blanchet, G., Friendly, M., Kindt, R., Legendre, P., McGlinn, D., Minchin, P., O'Hara, R., Simpson, G., Solymos, P., Henry, M., Stevens, H., Szoecs, E., Wagner, H., 2018. Vegan: community ecology package. R package version 2(6).

Pagel, J., Schurr, F.M., 2012. Forecasting species ranges by statistical estimation of ecological niches and spatial population dynamics. Global Ecol. Biogeogr. 21 (2), 293-304.

Palma, A.S, Vilarihno, M.G, Moita, M.T., 1998. Interannual trends in the longshore distribution of Dinophysis off the Portuguese coast. In: Reguera, B., Blanco, J., Fernández, M.L., Wyatt, T (eds) Harmful Algae. Xunta de Galicia and 

Compostela, pp. 124-127.

1014

1015

1016

1017

1018

1019

1020

1021

1022

1023

1024

1025

1026

1027

1028

1029

1030

1031

1032

1033

Papiol, G.G., Beuzenberg, V., Selwood, A.I., MacKenzie, L., Packer, M.A., 2016. The use of a mucus trap by Dinophysis acuta for the capture of Mesodinium rubrum prey under culture conditions. Harmful Algae 58, 1-7.

Park, M.G., Kim, S., Kim, H.S., Myung, G., Kang, Y.G., Yih, W., 2006. First successful culture of the marine dinoflagellate Dinophysis acuminata. Aquat. Microb. Ecol. 45 (2), 101-106.

Paterson, R.F., McNeill, S., Mitchell, E., Adams, T., Swan, S.C., Clarke, D., Miller, P.I., Bresnan, E., Davidson, K., 2017. Environmental control of harmful dinoflagellates and diatoms in a fjordic system. Harmful algae 69, 1-17.

Pérez-Santos, I., Garcés-Vargas, J., Schneider, W., Ross, L., Parra, S., Valle-Levinson, A., 2014. Double-diffusive layering and mixing in Patagonian fjords. Prog. Oceanogr. $129,35-49$.

Pickard, G., 1971. Some physical oceanographic features of inlets of Chile. J. Fish. Board Can. 28 (8), 1077-1106.

Pinilla, E., Castillo, M., Pérez-Santos, I., Venegas, O., Valle-Levinson, A., 2020. Water age variability in a Patagonian fjord. J. Mar. Syst. 103376.

Pizarro, G., Alarcón, C., Franco, J., Palma, M., Escalera, L., Reguera, B., Vidal, G., Guzmán, L., 2011. Spatial distribution of Dinophysis spp. and detection in water of DSP toxins through diaion resins (summer 2006, Los Lagos Region, Chile). Ciencia y Tecnología del Mar 34 (1/2), 31-48. 
1034

1035

1036

1037

1038

1039

1040

1041

1042

1043

1044

1045

1046

1047

1048

1049

1050

1051

1052

1053

1054

1055

1056

Pizarro, G., Escalera, L., González-Gil, S., Franco, J.M., Reguera, B., 2008. Growth, behaviour and cell toxin quota of Dinophysis acuta during a daily cycle. Mar. Ecol. Prog. Ser. 353, 89-105.

Pizarro, G., Moroño, Á., Paz, B., Franco, J., Pazos, Y., Reguera, B., 2013. Evaluation of passive samplers as a monitoring tool for early warning of Dinophysis toxins in shellfish. Mar. Drugs 11 (10), 3823-3845.

Pizarro, G., Paz, B., Alarcón, C., Toro, C., Frangópulos, M., Salgado, P., Olave, C., Zamora, C., Pacheco, H., Guzmán, L., 2018. Winter distribution of toxic, potentially toxic phytoplankton, and shellfish toxins in fjords and channels of the Aysén region, Chile. Lat. Am. J. Aquat. Res. 46 (1), 120-139.

Prado-Fiedler, R., 2000. Spring distribution of ammonium in fjords and inlets between Puerto Montt and laguna San Rafael. Ciencia y Tecnología del Mar 23, 15-24.

R Core Team, 2019. R: A language environment for statistical computing. R Foundation for Statistical Computing, Vienna, Austria. URL https://www.R-project.org/.

Raine, R., Berdalet, E., Yamazaki, H., Jenkinson, I., Reguera, B., 2018. Key questions and recent research advances on Harmful Algal Blooms in stratified systems. In: Glibert, P., Berdalet, E., Burford, M., Pitcher, G., Zhou, M. (eds) Global Ecology and Oceanography of Harmful Algal Blooms. Ecological Studies, 232: 165-186.

Regueiro, J., Rossignoli, A.E., Álvarez, G., Blanco, J., 2011. Automated on-line solidphase extraction coupled to liquid chromatography-tandem mass spectrometry for determination of lipophilic marine toxins in shellfish. Food Chem. 129 (2), 533-540.

Reguera, B., Bravo, I., Mariño, J., Campos-Loriz, M.J., Fraga, S., Carbonell, A., 1993. Trends in the occurrence of Dinophysis spp. in Galician coastal waters. In: 
Smayda,T.J., Shimizu, Y. (Eds.), Toxic Phytoplankton Blooms in the Sea. Elsevier, Amsterdam, pp. 559-564.

Reguera, B., Garcés, E., Pazos, Y., Bravo, I., Ramilo, I., González-Gil, S., 2003. Cell cycle patterns and estimates of in situ division rates of dinoflagellates of the genus Dinophysis by a postmitotic index. Mar. Ecol. Prog. Ser. 249, 117-131.

Reguera, B., Riobó, P., Rodríguez, F., Díaz, P., Pizarro, G., Paz, B., Franco, J., Blanco, J., 2014. Dinophysis toxins: causative organisms, distribution and fate in shellfish. Mar. Drugs 12 (1), 394-461.

Reguera, B., Velo-Suárez, L., Raine, R., Park, M.G., 2012. Harmful Dinophysis species: A review. Harmful Algae 14, 87-106.

Rial, P., Laza-Martínez, A., Reguera, B., Raho, N., Rodríguez, F., 2015. Origin of cryptophyte plastids in Dinophysis from Galician waters: results from field and culture experiments. Aquat. Microb. Ecol. 76 (2), 163-174.

Riisgaard, K., Hansen, P.J., 2009. Role of food uptake for photosynthesis, growth and survival of the mixotrophic dinoflagellate Dinophysis acuminata. Mar. Ecol. Prog. Ser. 381, 51-62.

Ross, O.N., Sharples, J., 2007. Phytoplankton motility and the competition for nutrients in the thermocline. Mar. Ecol. Prog. Ser. 347, 21-38.

Rountos, K.J., Kim, J.J., Hattenrath-Lehmann, T.K., Gobler, C.J., 2019. Effects of the harmful algae, Alexandrium catenella and Dinophysis acuminata, on the survival, growth, and swimming activity of early life stages of forage fish. Mar. Environ. Res. 148, 46-56.

Roy, S., Montresor, M., Cembella, A., 2018. Key questions and recent research advances on Harmful Algal Blooms in fjords and coastal embayments. In: Glibert, P., 
Berdalet, E., Burford, M., Pitcher, G., Zhou, M. (eds) Global Ecology and Oceanography of Harmful Algal Blooms. Ecological Studies, 232: 187-203.

Sauter, T., 2020. Revisiting extreme precipitation amounts over southern South America and implications for the Patagonian Icefields. Hydrol. Earth Syst. Sci. 24, 203-2016.

Schlitzer, R., 2019. Ocean Data View, https://odv.awi.de.

Schneider, W., Pérez-Santos, I., Ross, L., Bravo, L., Seguel, R., Hernández, F., 2014. On the hydrography of Puyuhuapi Channel, Chilean Patagonia. Prog. Oceanogr. 129, 818.

Seeyave, S., Probyn, T., Álvarez-Salgado, X., Figueiras, F., Purdie, D., Barton, E., Lucas, M., 2013. Nitrogen uptake of phytoplankton assemblages under contrasting upwelling and downwelling conditions: The Ría de Vigo, NW Iberia. Estuar. Coast. Shelf Sci. 124, 1-12.

Seeyave, S., Probyn, T., Pitcher, G., Lucas, M., Purdie, D., 2009. Nitrogen nutrition in assemblages dominated by Pseudo-nitzschia spp., Alexandrium catenella and Dinophysis acuminata off the west coast of South Africa. Mar. Ecol. Prog. Ser. 379, 91-107.

Seguel, M., Tocornal, M.A., Sfeir, A., 2005. Floraciones algales nocivas en los canales y fiordos del sur de Chile. Ciencia y Tecnología del Mar 28 (2), 5-13.

Sievers, H., Silva, N., 2008. Water masses and circulation in austral Chilean channels and fjords. In: N. Silva \& S. Palma (eds). Progress in the oceanographic knowledge of Chilean interior waters, from Puerto Montt to Cape Horn. Comité Oceanográfico Nacional - Pontificia Universidad Católica de Valparaíso, Valparaíso, 53-58. 
1103

1104

1105

1106

1107

1108

1109

1110

1111

1112

1113

1114

1115

1116

1117

1118

1119

1120

1121

1122

1123

1124

Silva, N., Calvete, C., 2002. Physical and chemical oceanographic features of southern Chilean inlets between Penas Gulf and Magellan Strait (Cimar-Fiordos 2 cruise). Ciencia y Tecnología del Mar 25, 23-28.

Sjöqvist, C., Lindholm, T., 2011. Natural co-occurrence of Dinophysis acuminata (Dinoflagellata) and Mesodinium rubrum (Ciliophora) in thin layers in a coastal inlet. J. Eukaryot. Microbiol. 58 (4), 365-372.

Smayda, T.J., 2002. Adaptive ecology, growth strategies and the global bloom expansion of dinoflagellates. J. Oceanogr. 58 (2), 281-294.

Smayda, T.J., Reynolds, C.S., 2001. Community assembly in marine phytoplankton: application of recent models to harmful dinoflagellate blooms. J. Plankton Res. 23 (5), 447-461.

Smith, M., Hansen, P.J., 2007. Interaction between Mesodinium rubrum and its prey: importance of prey concentration, irradiance and pH. Mar. Ecol. Prog. Ser. 338, 6170.

Stoecker, D.K., Johnson, M.D., de Vargas, C., Not, F., 2009. Acquired phototrophy in aquatic protists. Aquat. Microb. Ecol. 57 (3), 279-310.

Sullivan, J.M., Swift, E., Donaghay, P.L., Rines, J.E., 2003. Small-scale turbulence affects the division rate and morphology of two red-tide dinoflagellates. Harmful Algae 2 (3), 183-199.

Sutani, D., Utsumi, M., Kato, Y., Sugiura, N., 2014. Estimation of the changes in phytoplankton community composition in a volcanic acidotrophic Lake, Inawashiro, Japan. Jpn. J. Water Treat. Biol. 50 (2), 53-69. 
1125

1126

1127

1128

1129

1130

1131

1132

1133

1134

1135

1136

1137

1138

1139

1140

1141

1142

1143

1144

1145

1146

1147

1148

Swan, S.C., Turner, A.D., Bresnan, E., Whyte, C., Paterson, R.F., McNeill, S., Mitchell, E., Davidson, K., 2018. Dinophysis acuta in Scottish coastal waters and its influence on Diarrhetic Shellfish Toxin profiles. Toxins 10 (10), 399.

ter Braak, C.J., Verdonschot, P.F., 1995. Canonical correspondence analysis and related multivariate methods in aquatic ecology. Aquat. Sci. 57 (3), 255-289.

Uribe, J.C., García, C., Rivas, M., Lagos, N., 2001. First report diarrheic shellfish toxins in magellanic fiords, southern Chile. J. Shellfish Res. 20, 69-74.

Utermöhl, H., 1958. Zur vervollkommnung der quantitativen Phytoplankton-Methodik: Mitt. Int. Vee. Ther. Angew. Limnol. 9: 1-38.

Velo-Suárez, L., González-Gil, S., Gentien, P., Lunven, M., Bechemin, C., Fernand, L., Raine, R., Reguera, B., 2008. Thin layers of Pseudo-nitzschia spp. and the fate of Dinophysis acuminata during an upwelling-downwelling cycle in a Galician Ría. Limnol. Oceanogr. 53 (5), 1816-1834.

Velo-Suárez, L., Reguera, B., Garcés, E., Wyatt, T., 2009. Vertical distribution of division rates in coastal dinoflagellate Dinophysis spp. populations: implications for modelling. Mar. Ecol. Prog. Ser. 385, 87-96.

Villarino, M., Figueiras, F., Jones, K., Álvarez-Salgado, X.A., Richard, J., Edwards, A., 1995. Evidence of in situ diel vertical migration of a red-tide microplankton species in Ria de Vigo (NW Spain). Mar. Biol. 123 (3), 607-617.

Yamazaki, H., Kamykowski, D., 1991. The vertical trajectories of motile phytoplankton in a wind-mixed water column. Deep-Sea Res. 38 (2), 219-241.

Yasumoto, T., Oshima, Y., Sugawara, W., Fukuyo, Y., Oguri, H., Igarashi, T., Fujita, N., 1980. Identification of Dinophysis fortii as the causative organism of diarrhetic shellfish poisoning. Bull. Jpn. Soc. Sci. Fish. 46(11), 1405-1411. 
1149 Table 1. Niche parameters estimated with the Outlying Mean Index (OMI) analysis for 1150 Dinophysis acuta, D. acuminata and their potential prey (microplanktonic ciliates) at a 1151 fixed sampling station in Puyuhuapi Fjord during the $48 \mathrm{~h}$ study (February 26 - 28, 2019). 1152 Niche parameters are given as absolute values for each species. Inertia (total variability), 1153 OMI (marginality), Tol (Tolerance), Rtol (Residual Tolerance). $P$-values were calculated 1154 with 10,000 random permutations that yielded a higher value than the observed marginality 1155 (OMI). Bold values were significant $(p<0.05)$.

1156

\begin{tabular}{ccccccc}
\hline Species & Code & Inertia & OMI & Tol & Rtol & $p$-value \\
\hline Dinophysis acuta & Dacuta & 4.13 & 0.65 & 1.49 & 2.00 & $<\mathbf{0 . 0 1}$ \\
Dinophysis acuminata & Dacuminata & 6.33 & 1.83 & 1.90 & 2.61 & $<\mathbf{0 . 0 1}$ \\
Mesodinium spp. & Meso & 5.41 & 0.10 & 3.11 & 2.19 & $<\mathbf{0 . 0 1}$ \\
Leegaardiella sp. & Leeg & 4.33 & 0.01 & 1.46 & 2.85 & $<\mathbf{0 . 0 1}$ \\
Paratontonia spp. & Para & 7.74 & 2.02 & 2.88 & 2.84 & 0.84 \\
Strombidium spp. & Strom & 5.81 & 0.49 & 2.97 & 2.36 & $<\mathbf{0 . 0 1}$ \\
Pseudotontonia sp. & Pse & 4.00 & 0.36 & 1.63 & 2.02 & $<\mathbf{0 . 0 1}$ \\
Laboea sp. & Labo & 4.68 & 0.91 & 1.86 & 1.91 & $<\mathbf{0 . 0 1}$ \\
Lohmanniella sp. & Loh & 4.63 & 0.16 & 2.21 & 2.27 & $<\mathbf{0 . 0 1}$ \\
Cyrtostrombidium sp. & Cyr & 1.88 & 0.25 & 0.12 & 1.52 & 0.29 \\
\hline
\end{tabular}

1157

1158

1159

1160

1161

1162

1163 
1164 Table 2. PERMANOVA analysis based on Euclidean method with the environmental 1165 variables explaining the cell densities of $D$. acuta and D. acuminata at a fixed sampling 1166 station in Puyuhuapi Fjord during the 48 h study (February $26-28,2019)$ ). $P$-values were 1167 calculated with 10,000 random permutations. Bold values were significant $(p<0.05)$.

\begin{tabular}{lccccc}
\hline \multicolumn{1}{c}{ Predictive variables } & Df & SS & $\mathrm{R}^{2}$ & Pseudo $-\mathrm{F}$ & $\operatorname{Pr}>F$ \\
\hline Depth & 1 & 5.44 & 0.00215 & 0.7444 & 0.4635 \\
Temperature & 1 & 313.87 & 0.12447 & 42.9327 & $<\mathbf{0 . 0 5}$ \\
Salinity & 1 & 323.26 & 0.12819 & 44.2176 & $<\mathbf{0 . 0 5}$ \\
PAR & 1 & 38.30 & 0.01518 & 5.2389 & $<\mathbf{0 . 0 5}$ \\
Turbulence & 1 & 18.27 & 0.00724 & 2.4992 & 0.0851 \\
Residuals & 18 & 1359.78 & 0.53926 & & \\
Total & 6 & & & & \\
& 19 & 2521.57 & 1.00000 & & \\
\hline
\end{tabular}
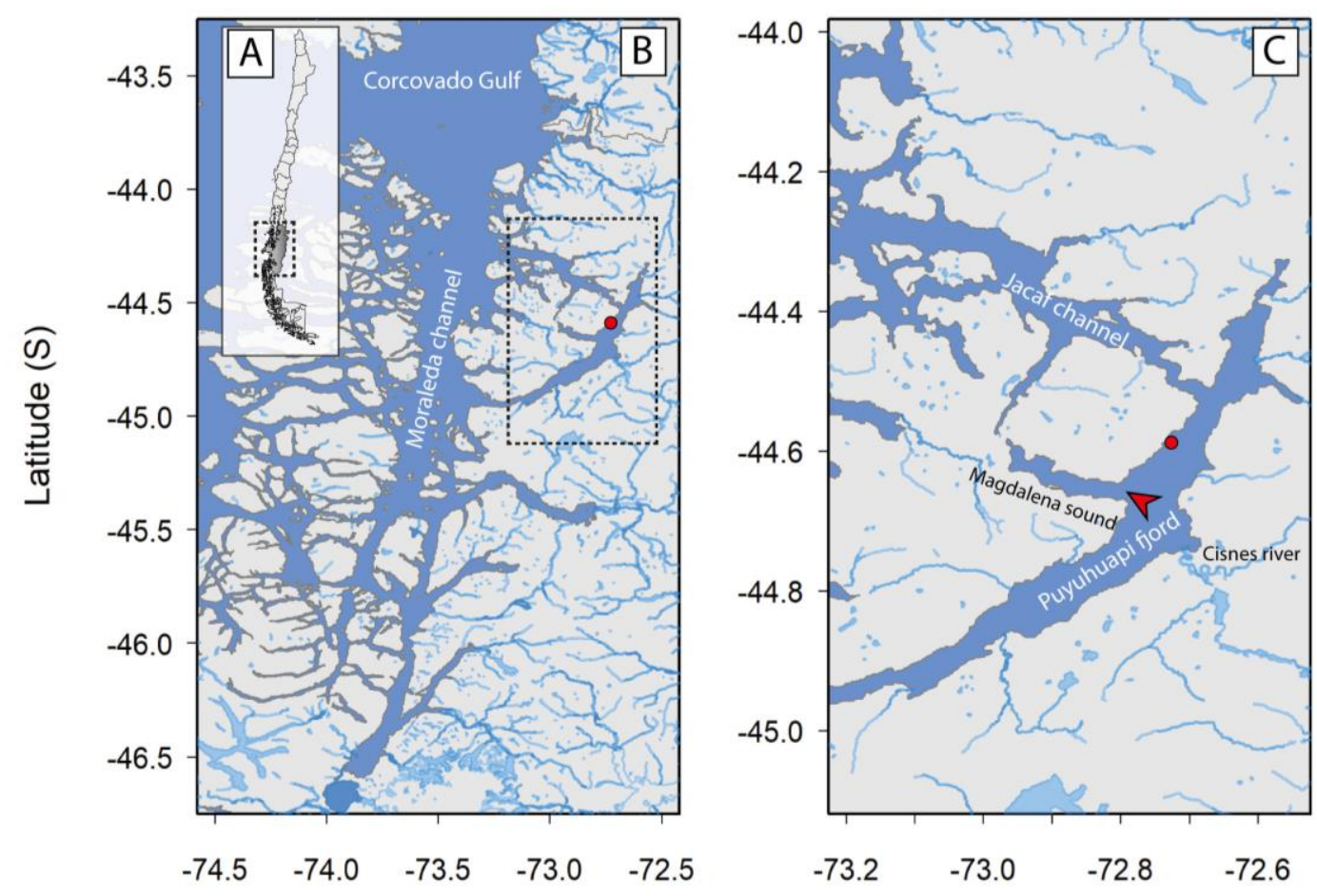

Longitude $(\mathrm{W})$

Figure 1. Map of the study area showing (A) Chile (the box delimits the Aysén region); (B)

1172 Aysén Region, Chilean Patagonia and its channels and fjords (the box delimits Puyuhuapi

1173 fjord); (C) Puyuhuapi Fjord and its main connections with the open sea, and freshwater 
1174 sources. The red circle indicates the fixed sampling station for the $48 \mathrm{~h}$ study and the red

1175 arrow, the confluence zone between Magdalena Sound and Puyuhuapi Fjord.
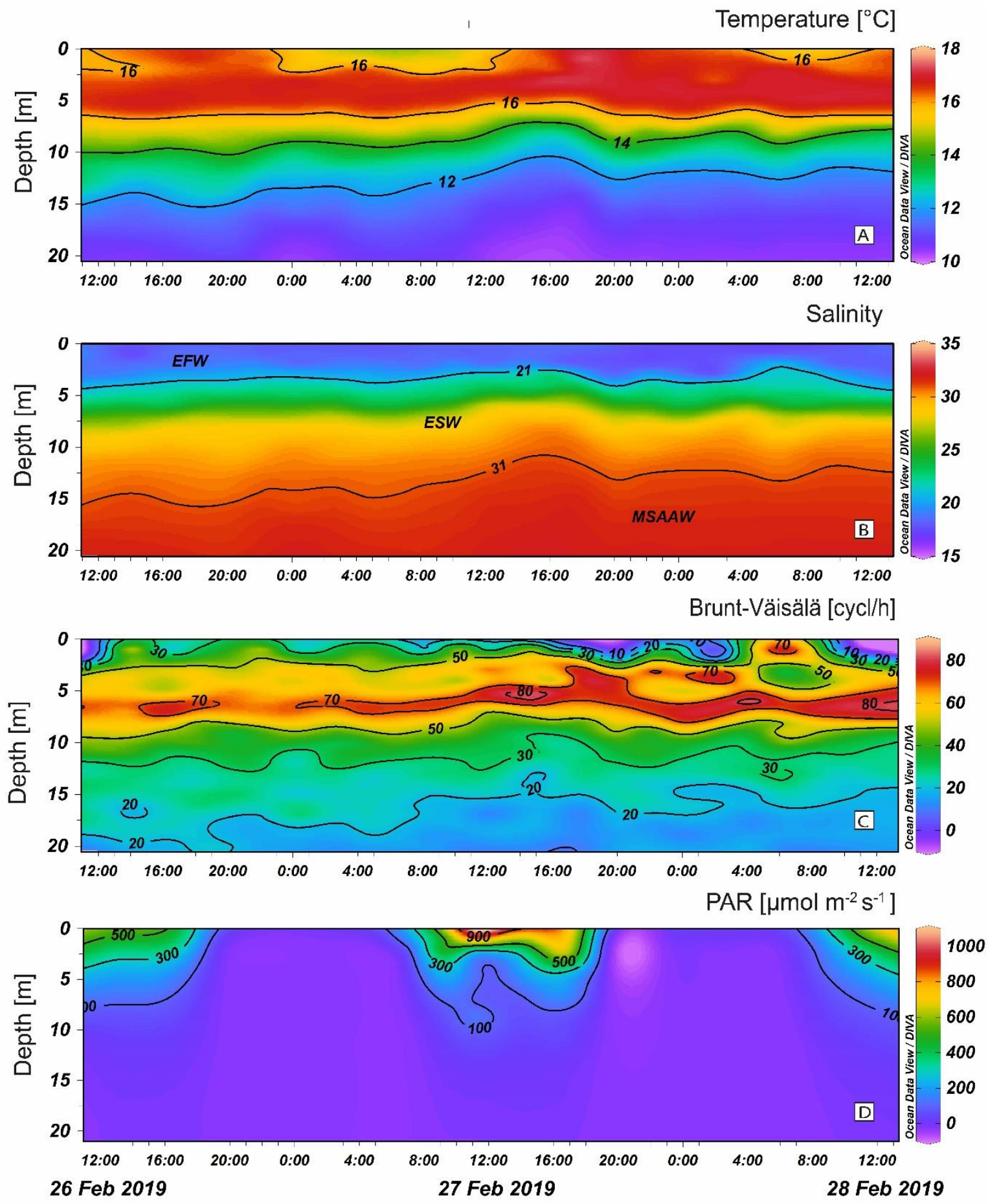
1177 Figure 2. Vertical distribution of (A) temperature $\left({ }^{\circ} \mathrm{C}\right)$; (B) salinity; (C) Brünt-Väisälä 1178 frequency and (D) Photosynthetically Active Radiation (PAR) from measurements 1179 obtained every $2 \mathrm{~h}$ during $48 \mathrm{~h}$ at the fixed station with a Sea-Bird SBE-19 Conductivity 1180 Temperature - Depth (CTD) probe cast from the surface to $50 \mathrm{~m}$ depth (A-C); and a 1181 Photosynthetically Active Radiation (PAR) sensor (D). Acronyms for water layers in 1182 Puyuhuapi Fjord, classified according to Pérez-Santos et al. (2019), stand for: EFW = 1183 Estuarine Fresh Water; ESW = Estuarine Salty Water; MSAAW = Modified Subantarctic 1184 water).

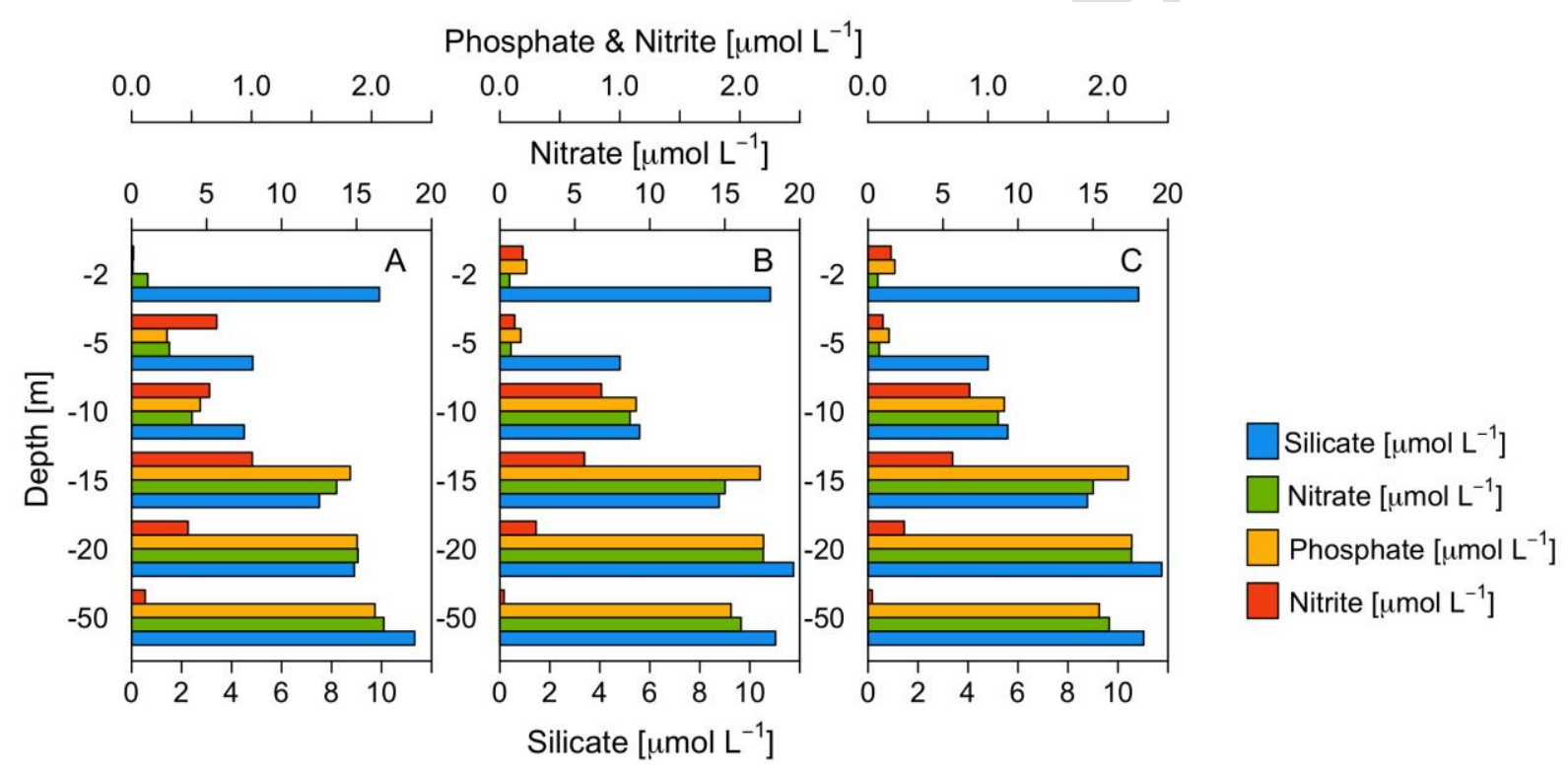

1186 Figure 3. Vertical profiles of dissolved nutrients (silicate, nitrate, nitrite, and phosphate) at 1187 the fixed sampling station on: (A) 27 February; (B) 28 February and (C) 29 February 2019 1188 at $12: 00 \mathrm{~h}$ during the $48 \mathrm{~h}$ study. 


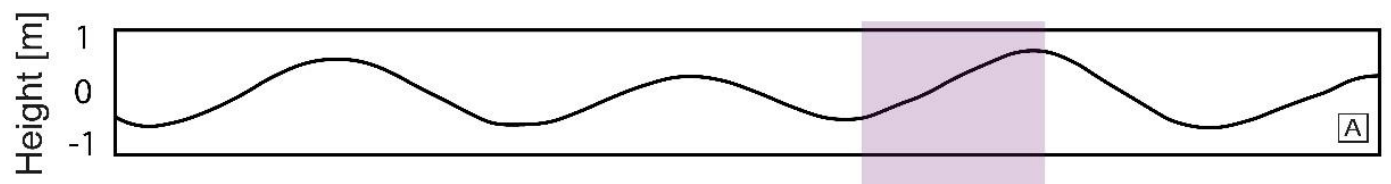

Dinophysis acuta [Cells L-1]

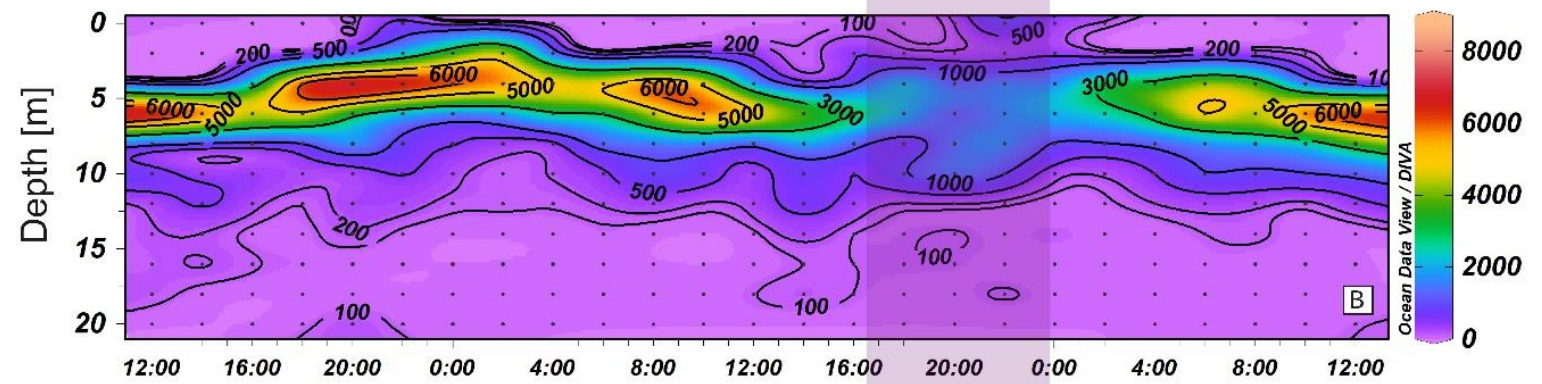

Dinophysis acuminata [Cells L-1]

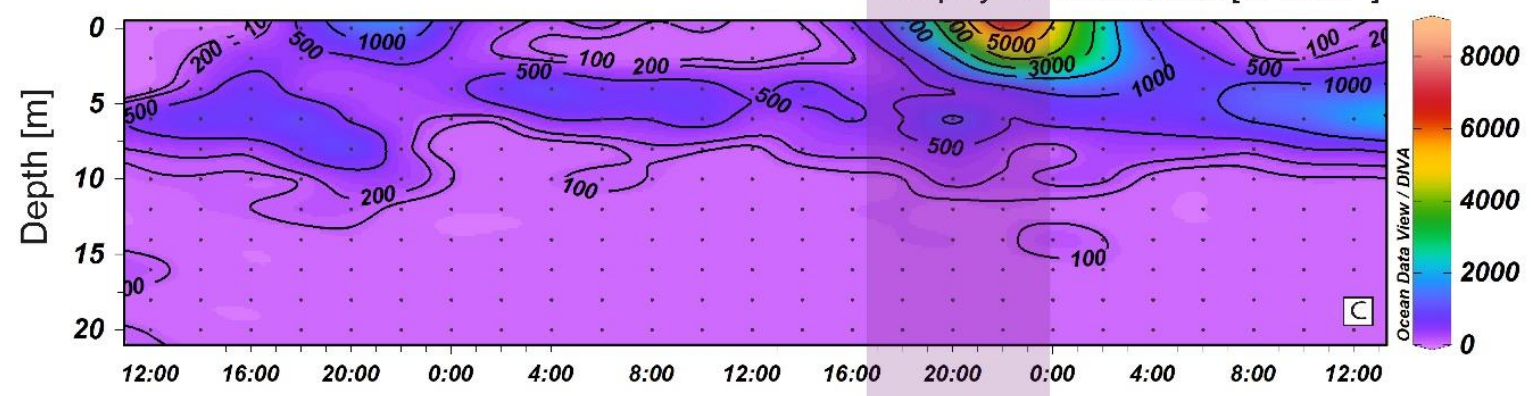

Mesodinium spp. [Cells L-1]
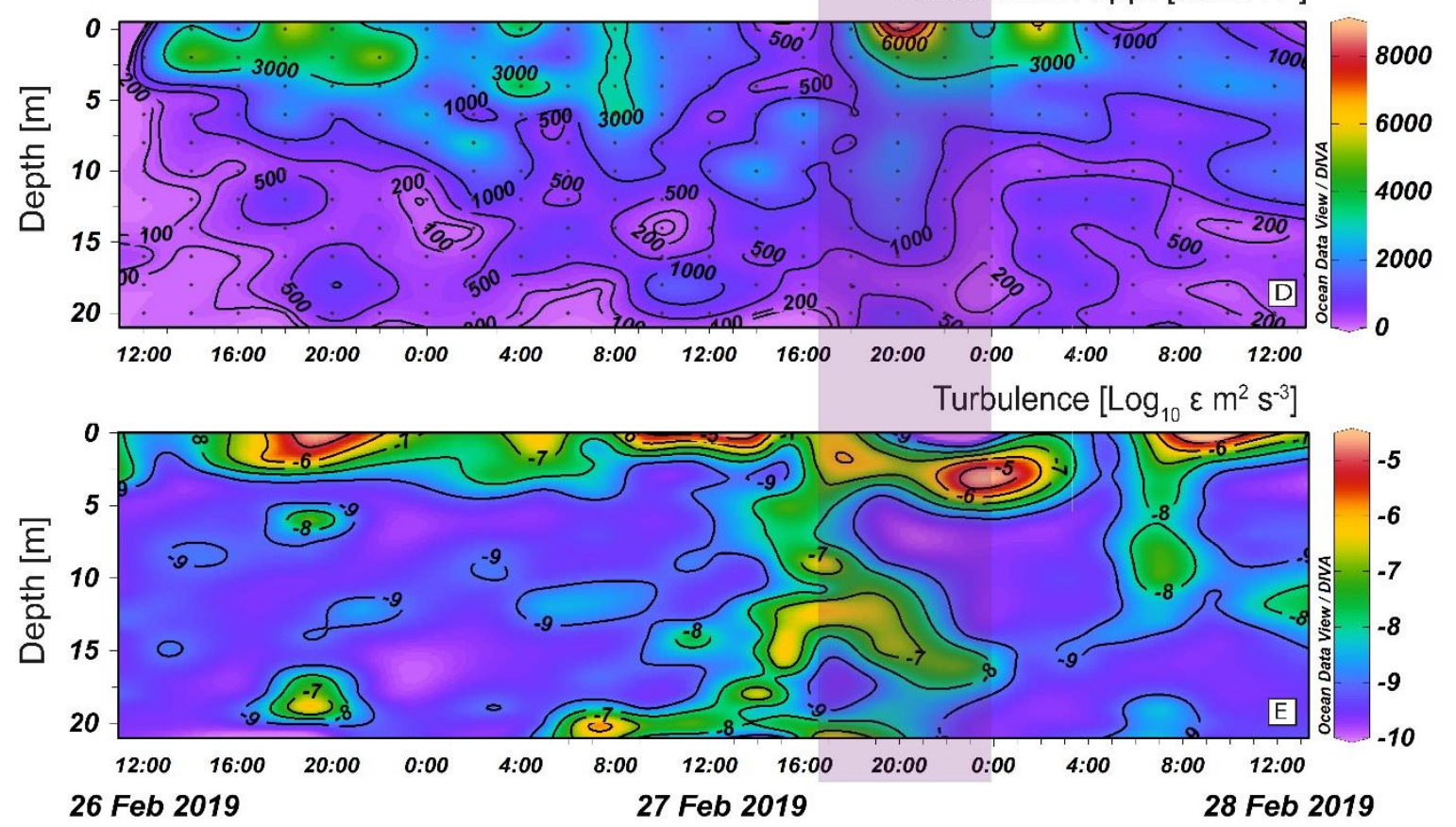

1194 Figure 4. Vertical distribution of (A) Tidal amplitude; cell densities of (B) Dinophysis

1195 acuta; (C) Dinophysis acuminata; (D) Mesodinium spp.; (E) Turbulent kinetic energy 
1196 dissipation rate $(\varepsilon)$ derived from the microstructure profiler deployed at the fixed station 1197 during the $48 \mathrm{~h}$ study (February $26-28,2019)$. Shaded area indicates the hours of 1198 incoming tides and increased turbulence during the second day.
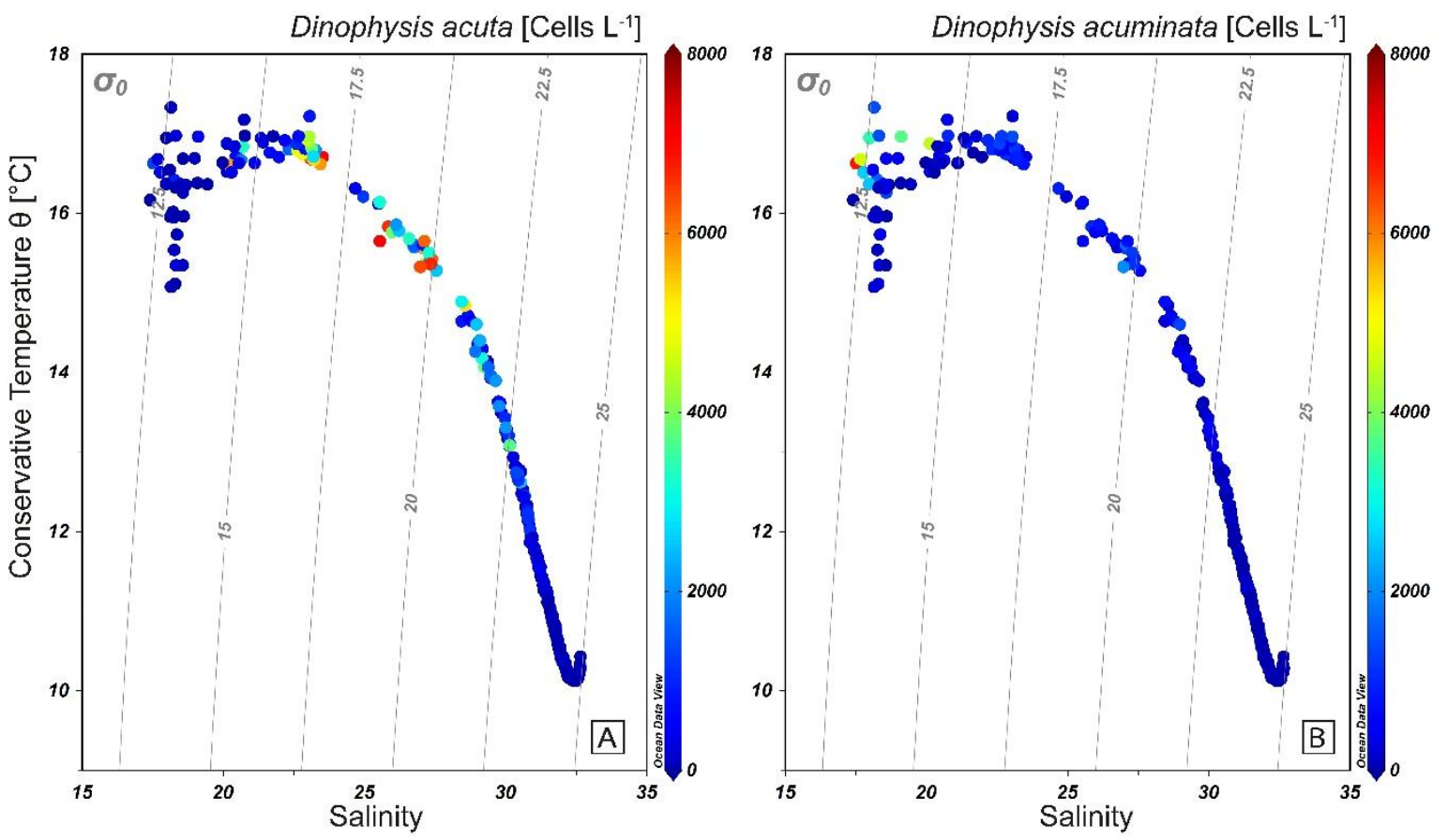

1200

1201

Figure 5. Cell densities of D. acuta (A) and D. acuminata (B) plotted over TS diagrams.

1202 Data from the fixed sampling station during the 48 h study (February 26 - 28, 2019). Gray 1203 contour lines represent isopycnals. 

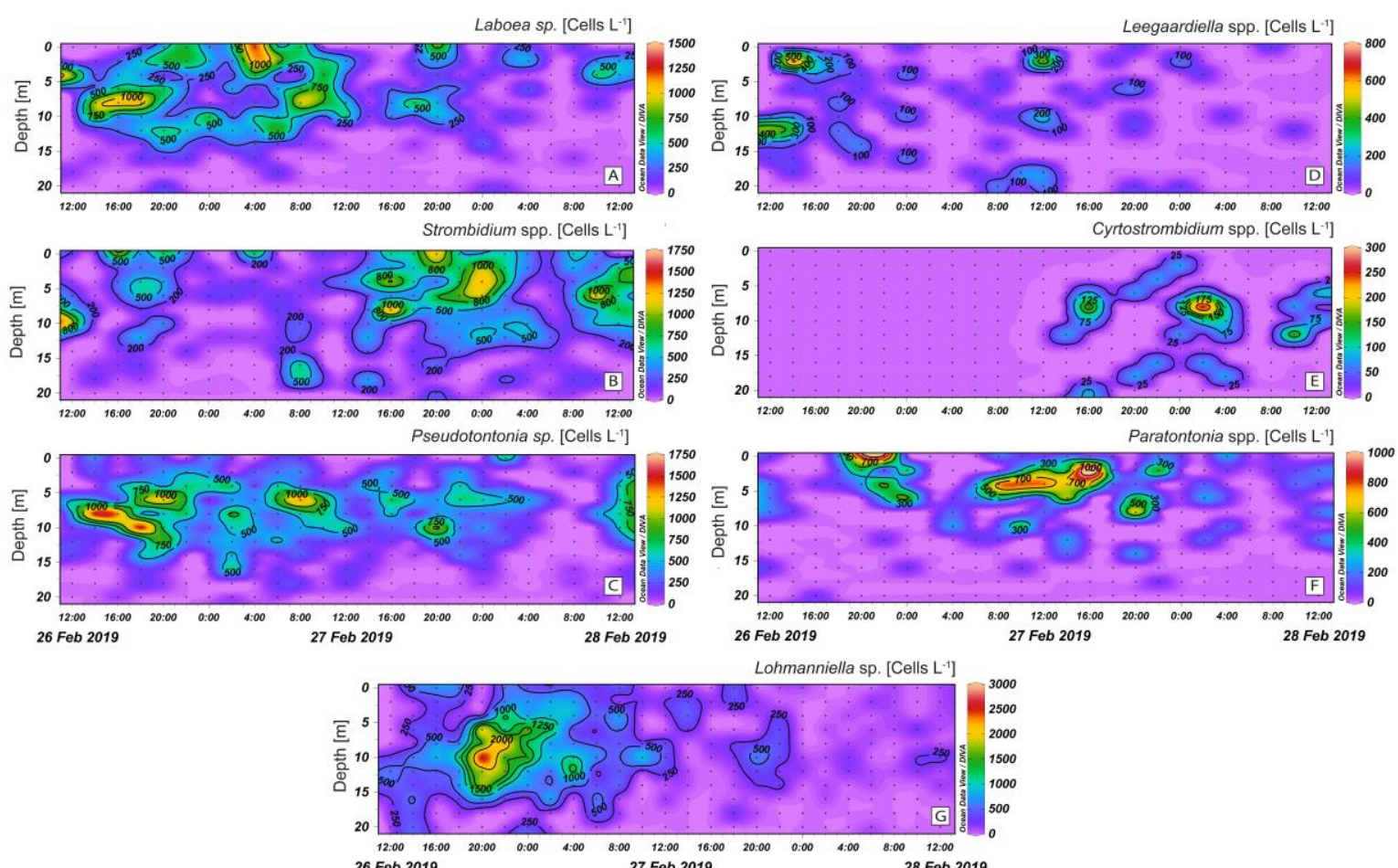

1212 Figure 6. Vertical distribution of potential plastid-bearing micro-ciliate prey for

1213 Dinophysis species: (A) Laboea sp.; (B) Strombidium spp.; (C) Pseudotontonia sp.; (D)

1214 Leegaardiella spp.; (E) Cyrtostrombidium sp.; (F) Paratontonia spp.; (G) Lohmanniella sp.

1215 at the fixed sampling station during the $48 \mathrm{~h}$ study (February $26-28,2019$ ). Note the

1216 different scale between panels. 

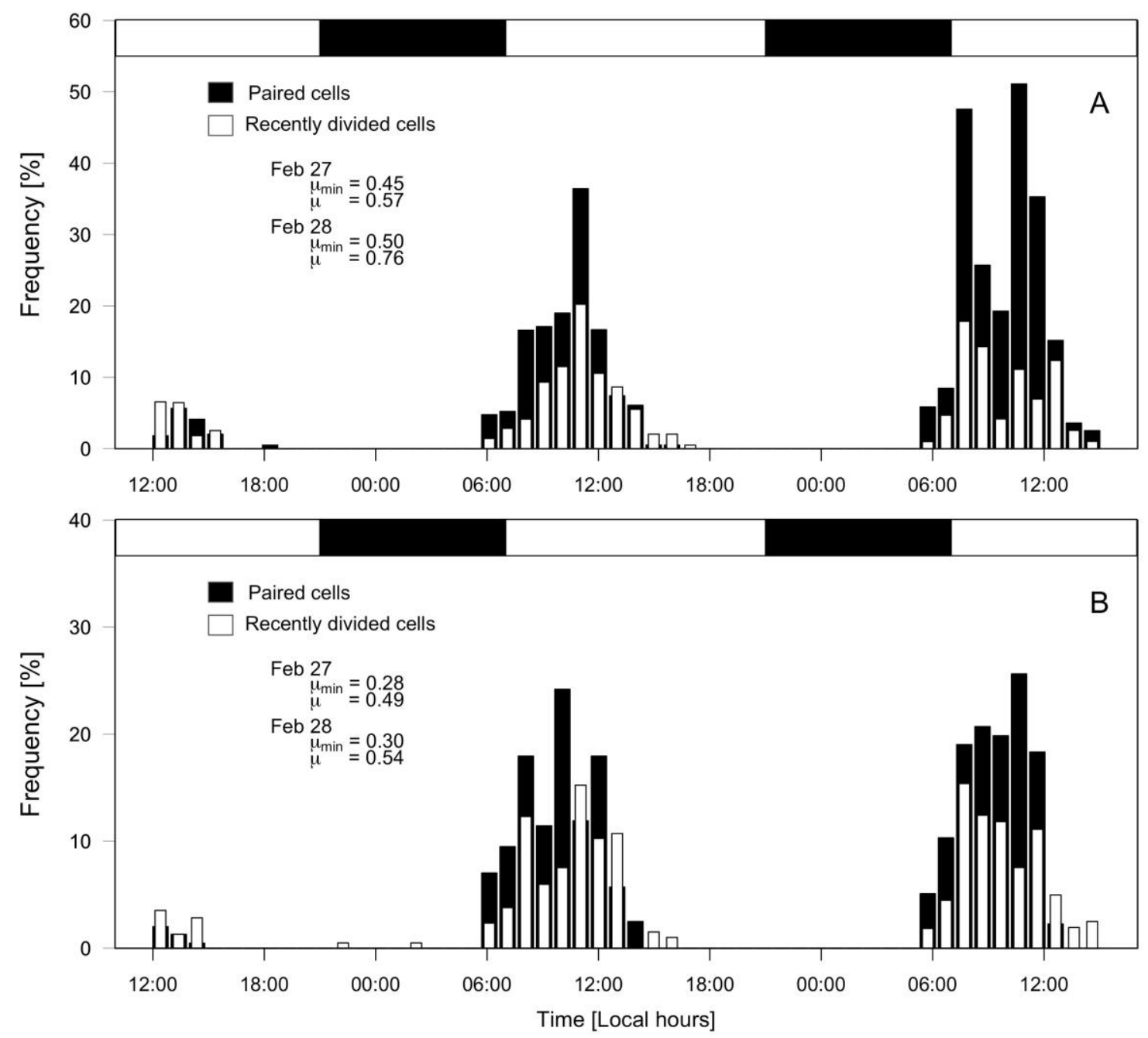

1218 Figure 7. Cell cycle study, 26 - 28 February 2019. Distribution of frequencies (\%) of paired 1219 (dividing, black bars) and recently divided (white bars) cells of: (A) D. acuta; (B) D. 1220 acuminata during a $48 \mathrm{~h}$ monitoring of cell cycle stages. Horizontal bar at top of graphs 1221 indicates period between sunset and sunrise. Note the different scale between panels. 
Chl a fluorescence $\left[\mu \mathrm{g} \mathrm{L}^{-1}\right]$

$\begin{array}{llllll}0 & 2 & 4 & 6 & 8 & 10\end{array}$
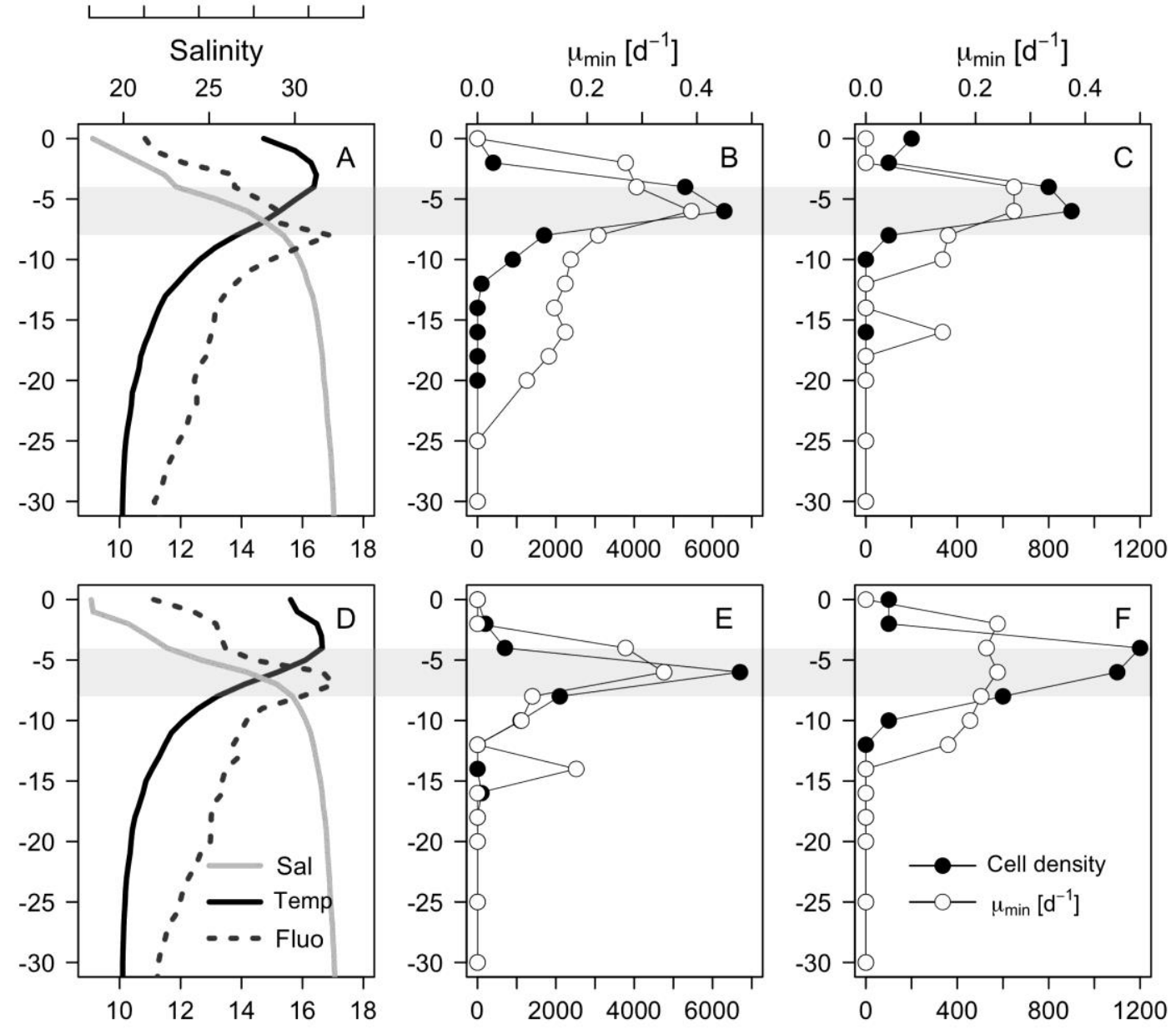

1222

Temperature $\left[{ }^{\circ} \mathrm{C}\right]$

D. acuta [cells $\mathrm{L}^{-1}$ ]

D. acuminata [cells $\mathrm{L}^{-1}$ ]

1223 Figure 8. Vertical profiles of (A, D) Temperature, salinity and chl $a$ fluorescence; (B, E)

1224 Dinophysis acuta and minimum division rate estimates at specific depths $\left(\mu_{\min }\right)_{z}\left(\mathrm{~d}^{-1}\right) ;(\mathrm{C}$,

1225 F) $D$. acuminata and minimum division rate estimates at specific depths $\left(\mu_{\min }\right)_{\mathrm{z}}\left(\mathrm{d}^{-1}\right)$ at

1226 10:00 h at the fixed sampling station on 27 February (top panels) and 28 February (bottom

1227 panels) 2019. The shadowed layer indicates the pycnocline position. Note the different

1228 scale between panels with D. acuta and D. acuminata. 

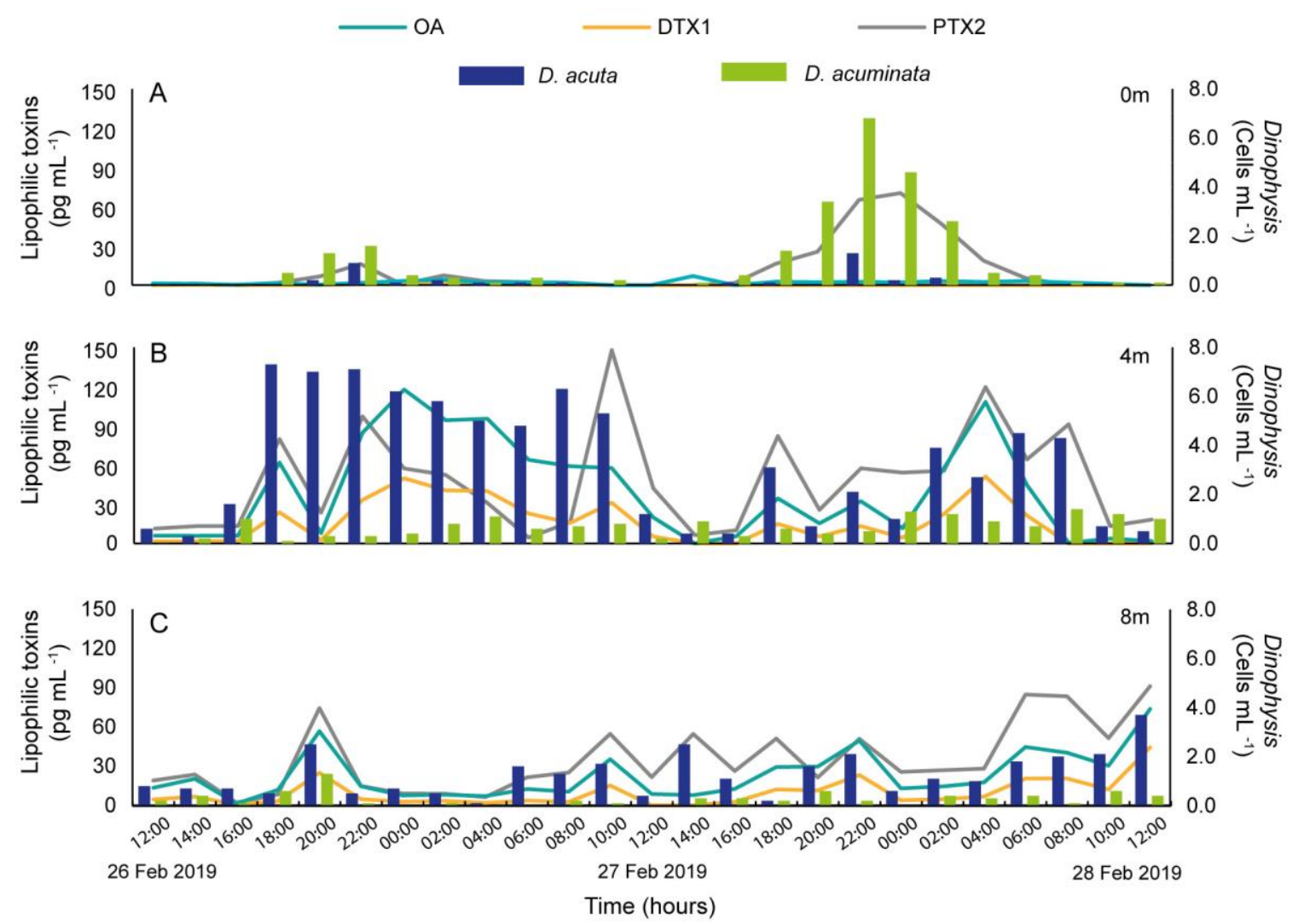

Figure 9. Distribution of lipophilic toxins concentration $\left(\mathrm{pg} \mathrm{mL}^{-1}\right)$ in phytoplankton concentrates, and Dinophysis cell densities (cells $\mathrm{mL}^{-1}$ ) at three depths: (A) $0 \mathrm{~m}$; (B) $4 \mathrm{~m}$; (C) $8 \mathrm{~m}$, at the fixed sampling station during the $48 \mathrm{~h}$ study (February $26-28,2019$ ). 

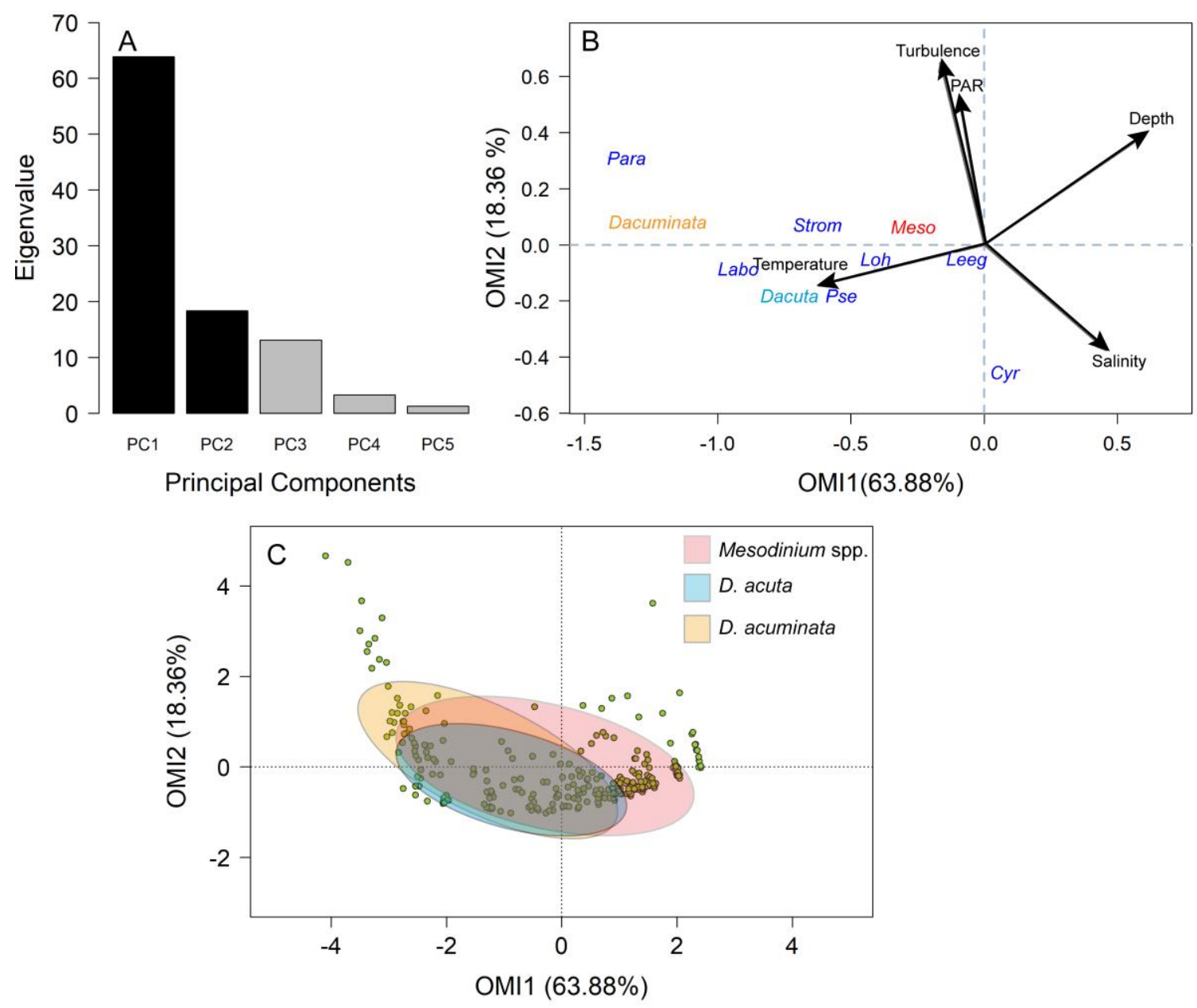

Figure 10. Outlying Mean Index (OMI) analysis of Dinophysis acuta, D. acuminata and

1236 co-occurring plastid-bearing micro-ciliates. (A) Bar plot of the eigenvalue in percentages

1237 of the total sum. Black bars are the chosen factorial axis PC1 (OMI1) and PC2 (OMI2);

1238 (B) Representation of the significant species' realized niche positions on the first two 1239 factorial axes with the canonical weights of environmental variables. The niche positions 1240 of Dinophysis acuta (light blue), D. acuminata (orange), their putative prey Mesodinium 1241 (red), and the ciliates (dark blue); (C) Realized niche breath of D. acuta (light blue), D. 1242 acuminata (orange) and the ciliate Mesodinium (red) found within the environmental 1243 space. Green dots represent the samples. 